San Jose State University

SJSU ScholarWorks

Master's Theses

Master's Theses and Graduate Research

1992

\title{
Aerobic bacteria of northern fur seal (Callorhinus ursinus) pups on the Pribilof (USA) Islands and Medny (USSR) Island
}

Matthew Anderson Burd

San Jose State University

Follow this and additional works at: https://scholarworks.sjsu.edu/etd_theses

\section{Recommended Citation}

Burd, Matthew Anderson, "Aerobic bacteria of northern fur seal (Callorhinus ursinus) pups on the Pribilof (USA) Islands and Medny (USSR) Island" (1992). Master's Theses. 293.

DOI: https://doi.org/10.31979/etd.3zdv-yrsb

https://scholarworks.sjsu.edu/etd_theses/293

This Thesis is brought to you for free and open access by the Master's Theses and Graduate Research at SJSU ScholarWorks. It has been accepted for inclusion in Master's Theses by an authorized administrator of SJSU ScholarWorks. For more information, please contact scholarworks@sjsu.edu. 


\section{INFORMATION TO USERS}

This manuscript has been reproduced from the microfilm master. UMI films the text directly from the original or copy submitted. Thus, some thesis and dissertation copies are in typewriter face, while others may be from any type of computer printer.

The quality of this reproduction is dependent upon the quality of the copy submitted. Broken or indistinct print, colored or poor quality illustrations and photographs, print bleedthrough, substandard margins, and improper alignment can adversely affect reproduction.

In the unlikely event that the author did not send UMI a complete manuscript and there are missing pages, these will be noted. Also, if unauthorized copyright material had to be removed, a note will indicate the deletion.

Oversize materials (e.g., maps, drawings, charts) are reproduced by sectioning the original, beginning at the upper left-hand corner and continuing from left to right in equal sections with small overlaps. Each original is also photographed in one exposure and is included in reduced form at the back of the book.

Photographs included in the original manuscript have been reproduced xerographically in this copy. Higher quality $6 " \times 9$ " black and white photographic prints are available for any photographs or illustrations appearing in this copy for an additional charge. Contact UMI directly to order.

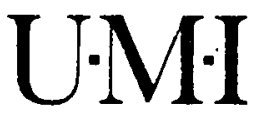




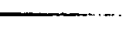


Aerobic bacteria of northern fur seal (Callorhinus ursinus) pups on the Pribilof (USA) Islands and Medny (USSR) Island

Burd, Matthew Anderson, M.S.

San Jose State University, 1992 
$-$ 


\title{
AEROBIC BACTERIA OF NORTHERN FUR SEAL (CALLORHINUS URSINUS)
}

PUPS ON THE PRIBULOF (USA) ISLANDS AND MEDNY (USSR) ISLAND

\author{
A Thesis \\ Presented to \\ The Faculty of Moss Landing Marine Laboratories \\ San Jose State University
}

\author{
In Partial Fulfillment of the \\ Requirements for the Degree \\ Masters of Science in Marine Science
}

by

Matthew Anderson Burd

May 1992 


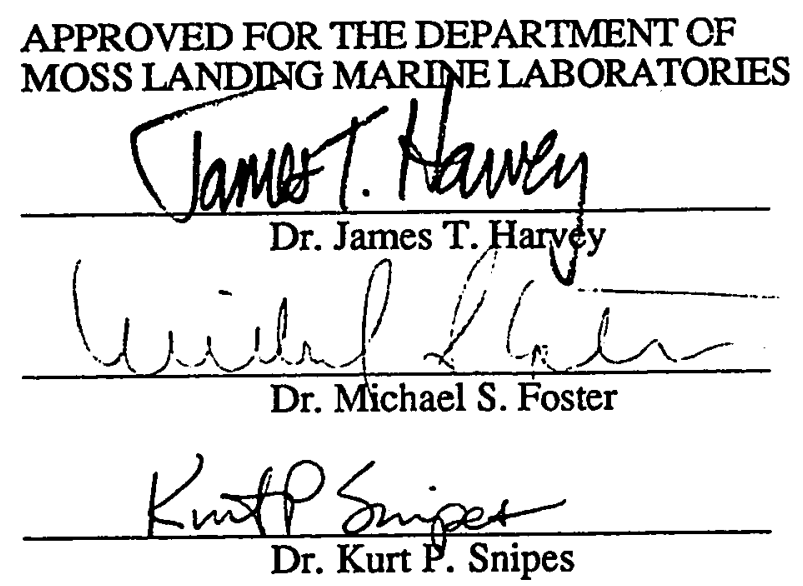

APPROVED FOR THE UNIVERSITY

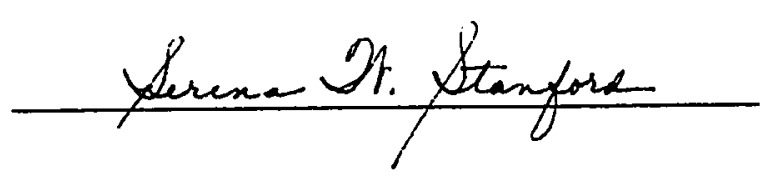




\section{ABSTRACT \\ AEROBIC BACTERIA OF NORTHERN FUR SEAL (CALLORHINUS URSINUS) PUPS ON THE PRIBILOF ISLANDS AND MEDNY ISLAND (USSR)}

by Matthew A. Burd

Differential prevalence (\%) of potentially pathogenic bacteria may contribute to differential pup mortality (\%) for rookeries of the Pribilof Islands and Medny Island. Aerobic bacteria were cultured from ocular, pharyngeal, and rectal swabs of pups. Weight and index of condition of pups with Pseudomonas aeruginosa, Acinetobacter lwoffi, groupD Salmonella, and Staphylococcus aureus were less than pups without these bacteria. Pups on Little Zapadni, Zapadni, Reef, Vostochni, and Morjovi rookeries had a significantly greater number of bacterial species, and pups on Reef and East Cliffs rookeries had a significantly greater number of species of pathogenic bacteria. Linear regressions between pup mortality, number of live pups, and number of bacterial species and number of species of pathogenic bacteria were not significant, indicating most bacteria did not affect pups. Prevalence (\%) of group-D Salmonella was correlated positively with pup mortality (\%) and may affect numbers of pups on Little Zapadni, Zapadni, Zapadni Reef, Vostochni, and Gorbatch rookeries. 


\section{CONTENTS}

PAGE

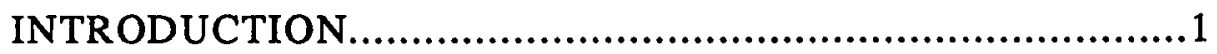

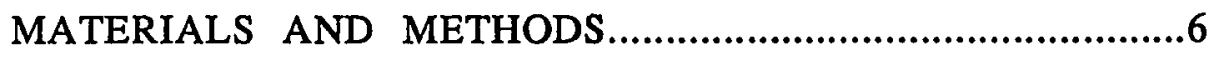

ASSESSMENT OF PUP CONDITION...................................6

COLLECTION OF CULTURE SWABS.................................6

ISOLATION OF BACTERIA........................................

IDENTIFICATION OF BACTERIA.................................

STATISTICAL ANALYSIS............................................. 9

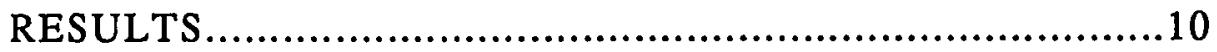

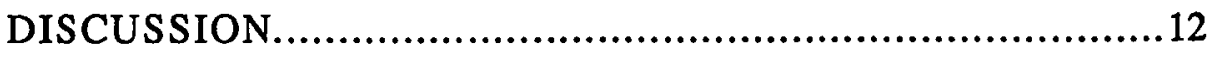

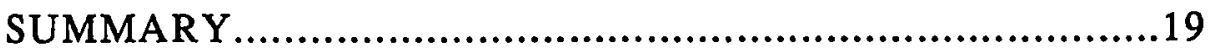

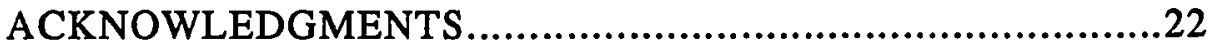

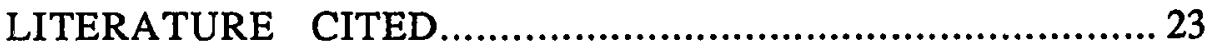

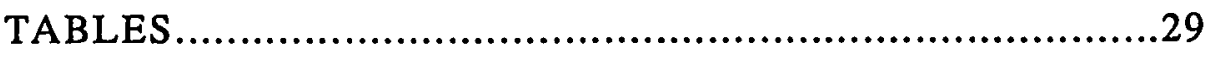

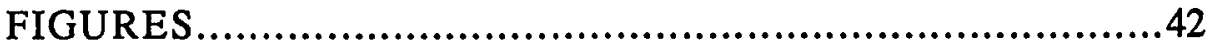




\section{TABLES}

1. Linear regressions of weight $(\mathrm{kg})$ with standard length $(\mathrm{cm})$, cranial width $(\mathrm{cm})$, index of fat thickness $(\mathrm{cm})$, and fore-flipper length $(\mathrm{cm})$ for northern fur seal pups on the Pribilof Islands and Medny island.

2. Comparison of mean weight $(\mathrm{kg})$ of males and females among rookeries using ANOVA, and between islands using Student's t-test, for northern fur seal pups of St. Paul, St. George, and Medny Islands.

3. Bacteria isolated from swabs of northern fur seal pups of the Pribilof Islands and Medny Island.

4. Percentage of northern fur seal pups ( $n=30$ /rookery) with bacterial taxa isolated from rectal swabs of pups of the Pribilof Islands and Medny Island.

5. Percentage of northern fur seal pups ( $n=30 /$ rookery) with bacterial taxa isolated from ocular swabs of pups of the Pribilof Islands and Medny Island.

6. Percentage of northern fur seal pups ( $n=30 /$ rookery) with bacterial taxa isolated from throat swabs of pups of the Pribilof Islands and Medny Island.

7. Bacteria reported as pathogenic in Otariids.

8. Comparison of mean weight $(\mathrm{kg})$ of northern fur seal pups with and without a species of pathogenic bacterium isolated from rectal swabs using a Student's t-test.

9. Comparison of maan index $(\mathrm{kg})$ of condition of northern fur seal pups with and without a species of pathogenic bacterium isolated from rectal swabs using a Student's t-test.

10. Comparison of mean number of bacterial species $(F=6.93, P=0.0001)$ and mean number of species of pathogenic bacteria $(F=3.36, P=0.0001)$ per pup among rookeries of the Pribilof Islands and Medny Island using an ANOVA and Ryan- Einot- GabrielWelsch Q multiple comparison test. Means with the same letter are not different significantly. 
11. Comparison of mean number of bacterial species $(\mathrm{F}=3.84, \mathrm{P}=0.0252)$ and mean number of species of pathogenic bacteria ( $F=4.82, P=0.0103)$ per pup among St. Paul, St. George, and Medny Islands using ANOVA and Ryan- Einot- Gabriel- Welsch Q multiple comparison test. Means with the same letter are not different significantly.

12. Linear regressions of pup mortality (\%) and number of live pups with mean number of bacterial species and mean number of species of pathogenic bacteria per pup, and frequency of occurrence of species of pathogenic bacteria for rookeries of the Pribilof Islands.

13. Linear regressions of pup weight $(\mathrm{kg})$ and index of condition $(\mathrm{kg})$ with number of bacterial species and number of species of pathogenic bacteria per pup; mean weight and mean index of condition with mean number of bacterial species and mean number of species of pathogenic bacteria per pup, and frequency of occurrence of pathogenic bacteria for rookeries of the Pribilof Islands and Medny Island.

\section{FIGURES}

1. Location of rookeries of the Pribilof Islands (USA) and Medny Island (USSR).

2. Linear regression of prevalence (\%) of group-D Salmonella and pup mortality (\%) for Little Zapadni, Zapadni, Zapadni Reef, Vostochni, and Gorbatch rookeries of St. Paul Island. 


\section{INTRODUCTION}

The northern fur seal (Callorhinus ursinus) is a member of the family Otariidae and sexual dimorphism allows adults to be distinguished. Males reach $2.13 \mathrm{~m}$ in length and weigh about $182-272 \mathrm{~kg}$, and females reach $1.42 \mathrm{~m}$ in length and weigh about $43-50 \mathrm{~kg}$ (Lander 1979). At birth, pups weigh about 4.5-5.4 $\mathrm{kg}$ and measure about $64 \mathrm{~cm}$ in length (Lander 1979). Adult males come ashore in mid-May and establish territories on rookeries, whereas younger males arrive later in the summer and are confined to hauling grounds away from the breeding areas (Peterson 1965). In June, pregnant females come ashore and within two days give birth to a single pup (Peterson 1965). From 1 to $100(\bar{x}=60)$ females occur in a single males's territory (Peterson 1968). Females have a bicornuate, double-horned uterus which allows fertilization within a week after birth of her pup. Blastocyst implantation in the uterus is delayed for about four months, presumably ensuring adequate health of the female and synchronous pupping the next breeding season (Craig 1964). Pups are dependent on their mothers for food for the first three to four months of life (Gentry and Holt 1986). Five to six days after pups are born, mothers go to sea and feed returning five to six days later to suckle their pups for one to two days. This foraging-suckling cycle occurs an average 12 to 14 times during each breeding season (Gentry and Holt 1986). Pups enter the water in October and November and remain pelagic for one to three years.

Northern fur seals spend much of their lives at sea, but return to breeding grounds once a year to breed. There are six breeding populations of northern fur seals: 1) Pribilof Islands, 2) Commander Islands, 3) Robben Islands, 4) Kuril Islands, 5) Bogoslof Island, and 6) San Miguel Island (Loughlin 1989). St. Paul Island is located approximately $324 \mathrm{~km}$ north of Unalaska in the eastern Bering Sea. St. George Island is located approximately 64 $\mathrm{km}$ southeast of St. Paul Island. The Pribilof Islands (St. Paul and St. George) population is the greatest in number, consisting of about 800,000 individuals (Fowler 1985). The 
Commander Islands (Bering and Medny) are located approximately $350 \mathrm{~km}$ west of the Kumchatka Peninsula in the western Bering Sea, and consists of about 265,000 individuals (Lander 1980)

In the early 1800 's, an estimated 6 million northem fur seals occurred on the Pribilof Islands (Scheffer et al. 1984). By 1909, under heavy commercial exploitation, the herd numbered 300,000 (Lander 1980). Pup counts have been made on the Pribilof Islands since 1912 (Scheffer et al. 1984), but few data exist from 1924 to 1950. Since 1961, pup production on the Pribilof Islands has been assessed by the "shearing sample" method described by Chapman and Johnson (1968) and modified by York and Kozloff (1987). From 1950 to 1980, numbers of pups born on St. Paul Island has decreased. Current levels (1.4 million) probably are about one third what they were in the 1940's and early 1950's (Fowler 1985). From 1975 to 1983, numbers of pups born on St. George Island decreased 5.95\% per year, whereas numbers born on St. Paul Island decreased 6.7\% per year (York 1990). In 1988, an estimated 202,312 pups were born on St. Paul Island, significantly greater than 1987 (York and Antonelis 1988). Despite this increase in natality, the population of northern fur seals on the Pribilof Islands has remained relatively stable since 1984 (York 1990).

All causes of the fur seal decline (1950-1980) have not been identified, but may include the combined effects of harvesting females during 1956-68, entanglement in net material, weather, reduced prey availability, and disease (Loughlin 1989). The greatest influence on the population of fur seals during the past 30 years is postulated to be harvesting of females (York 1987). Fowler (1987) speculated entanglement in net material discarded from fishing vessels also contributed to the decline. Incidental catch by commercial fisheries is thought insignificant (Loughlin et al. 1983). Kenyon et al. (1954) and Lander (1979) reported starvation during prolonged periods of stormy weather as a major cause of death in 
young northern fur seals. Loughlin et al. (1986) described a decline in duration of feeding trips of northem fur seals during the past 20 years, indicating changes in prey availability may have occurred.

Disease affects pinnipeds and may have contributed to the decline (1950-1980) in numbers of northern fur seals on the Pribilof Islands. An epizootic killed more than 17,000 harbor seals (Phoca vitulina) in Scandinavian, German, and Dutch waters, and a seal morbillivirus was isolated from diseased seals (Cosby et al. 1988). Rand (1975) reported thousands of Galapagos sea lions (Arctocephalus townsendii) died during a 1970-71 epizootic, and suggested Pseudomonas aeruginosa was responsible for a nodular suppurative cellulitis. Stroud and Roffe (1979) reported bacterial infection was the primary cause of death in $27 \%$ of 68 marine mammals stranded on Oregon beaches. Bacterial infection may be a more important cause of morbidity and mortality than indicated because many animals were too decomposed to obtain bacteriological samples, and animals weakened by chronic infection may be more susceptible to predation (Stroud and Roffe 1979). Viral, bacterial, fungal, and metazoan parasites have been reported in marine mammals (Keyes 1965, Wilson and Sweeney 1970, Stroud and Dailey 1978, Waldorf and Vedros 1978), and these parasites may contribute to mortality of pups of northern fur seals.

Mortality of pups may be affected by predation, trauma from adults, inclement weather, starvation, parasites, and infectious disease. Gentry and Johnson (1981) observed northern sea lions (Eumetopias jubatus) eating pups in the water near St. George Island. Emaciation syndrome and hookworm disease caused mortality of pups on the Pribilof Islands for many years (Laukner 1985). Keyes (1965) necropsied 226 pups and reported malnutrition as the primary cause of death in $37.6 \%$ of the animals and traumatic lesions in $36.7 \%$ of the animals. Keyes et al. (1975) necropsied 244 pups from three study areas on St. Paul Island. Trauma from adults, including skull fracture, liver rupture, and bite wounds 
caused $2.9 \%$ of deaths, emaciation syndrome and hookworm disease $65.1 \%$ of deaths, and microbial infection $12.7 \%$ of deaths. Of 90 pups necropsied, Spraker (unpl. data 1987) reported starvation and trauma (65\%) were the most common diagnoses followed by infectious disease (14.5\%). Smith et al. (1977) reported Leptospira pomona was associated with a multiple hemorrhage syndrome in pups. From 1964 to 1978, infectious disease was the primary diagnosis (12\%) for cause of death in pups on the Pribilof Islands (Lander 1980) and mortality of pups caused by infectious disease may affect regulation of numbers of northern fur seals.

Survival of pups may contribute twofold to the regulation of northern fur seals considering increases in both pup mortality and the variance of pup mortality with population size (Fowler 1984). Microparasites (bacteria and viruses) may play a role analogous to predators; when host populations increase, direct transmission of microparasites is enhanced (Lack 1954). During periods of nutritional stress, pathogenicity of parasites is amplified contributing to density-dependent regulation of natural populations (Anderson and May 1979). Mortality of pups of northem fur seals on land is affected by disease, and probably is density-dependent (Lander and Kajimura 1976). Striking differences (3-39\%) in pup mortality are possible for rookeries of the Pribilof Islands (Lander and Kajimura 1976). In 1987, the Zapadni rookery of St. Paul Island, had the greatest estimated pup mortality (6.5\%) and the Ardiguen rookery the least (Briggs 1990). In 1985, the Staraya Artil rookery of St. George Island had the greatest pup mortality (3.16 \%) and the East rookery the least (1.5\%; Briggs 1990). Pinnipeds form dense aggregations on land at various times throughout the year. Harwood and Greenfell (1990) suggested increased disease transmission rates result from this behavior and predispose pinniped populations to epizootics. 
Northern fur seal pups aggregate in large pods during the breeding season (Peterson 1965). This behavior is thought to reduce trauma to pups from adults, but increases the transmission of ectoparasites and other potential disease agents (Keyes 1965). Pups are born on geographically distinct rookeries and pups remain on rookeries where they were born until they leave in mid-October. Contact among pups on different rookeries is thought minimal. Therefore, pups on different rookeries may have different different pathogenic bacteria. The purpose of this study was to determine if the differential prevalence (\%) of potentially pathogenic bacteria contribute to the differential pup mortality (\%) for rookeries of the Pribilof Islands and Medny Island. I define a pathogenic bacterium as any bacterium that was reported capable of causing disease in Otariids and is the only definition used throughout this paper.

This study determined the species and prevalence (\%) of bacteria of pups, and tested the hypotheses: 1) there are differences among rookeries in numbers of pups with potentially pathogenic species of bacteria; 2 ) rookeries and islands with greater relative pup mortality (\%) have a greater number of bacterial species and species of potentially pathogenic bacteria per pup; 3) rookeries and islands with a greater number of live pups have a greater number of bacterial species and species of potentially pathogenic bacteria per pup; 4) pup weight and an index of condition is correlated negatively with number of bacterial species and species of potentially pathogenic bacteria per pup; and 5) pup weight and index of condition is less in pups with a potentially pathogenic bacterium than pups without a potentially pathogenic species of bacterium. 


\section{MATERIALS AND METHODS}

\section{A. Assessment of Pup Condition}

Between 14-31 August 1990, three of six rookeries of St. George Island (USA), 12 of 14 rookeries of St. Paul Island (USA), and a single rookery of Medny Island (USSR) were sampled (Fig. 1). Thirty pups per rookery were selected randomly and sex, tag numbers, and morphometric measurements were recorded. Pups were placed in a bucket and weighed to the nearest $0.25 \mathrm{~kg}$ with a hanging scale. Standard length was measured to the nearest centimeter by placing the pup ventrally on a board and measuring a straight line from tip of snout to end of tail. Three additional measurements (measured to the nearest $0.1 \mathrm{~cm}$ ) were determined for pups of the Pribilof Islands only: 1) cranial width, determined using a caliper to measure the distance between insertion points of each ear pinnae, 2) index of fat thickness, determined using a caliper to measure the thickness of a pinch behind the right fore-flipper, and 3) fore-flipper length, determined by bending the fore-flipper at the wrist and measuring from base of bend at the wrist to end of longest digit. An index of condition was calculated by dividing pup weight by standard length, and multiplying by the index of fat thickness.

\section{B. Collection of Culture Swabs}

Pups were restrained after measurements were determined and rectal, ocular, and pharyngeal swabs were used to collect bacteria. Ocular swabs were collected by spreading the upper and lower eyelids, and gently pressing the medial canthus allowing the nictitating membrane to unfold. A sterile rayon tipped swab (Cultureswab Transport System, DIFCO, Surrey, UK) was rolled across the palpebral conjunctiva and placed into AMIES medium without charcoal. Pharyngeal swabs were collected by opening the mouth and waiting for the pup to inhale. When a breath was taken, the tongue dropped and a wooden tongue 
depressor was inserted deep into the oral cavity. A sterile swab was rolled across the laryngo-pharynx and placed into AMIES medium without charcoal. Rectal swabs were collected by lifting the pup and spreading the hind flippers. A sterile swab was inserted approximately $7 \mathrm{~cm}$ into the rectum, rolled against the rectal wall, removed, and placed into AMIES medium without charcoal. There was no laboratory on St. George Island; therefore, on 19 August 1991, swabs in transport medium from the North, Zapadni, and East rookeries were transported to St. Paul Island and streaked onto primary isolation media. Maximum time between sampling and primary isolation was 72 hours for samples from St. George Island. Swabs from St. Paul and Medny Islands were streaked onto primary isolation media the same day they were taken.

C. Isolation of Bacteria

Chocolate II Agar (BBL, Maryland, USA) plates were inoculated with ocular swabs of pups from all rookeries. Trypticase Soy Agar with 5\% Sheep Blood (TSA II; BBL, Maryland, USA) plates were inoculated with pharyngeal and rectal swabs from St. George Island. MacConkey II Agar (BBL, Maryland, USA) and Hektoen Enteric Agar (BBL, Maryland, USA) plates were inoculated with rectal swabs from all locations and broken-off into Selenite-F Broth (BBL, Maryland, USA), incubated for 12 to 18 hours at $37^{\circ}$ Celsius, and a loopful of the broth was streaked onto Hektoen Enteric Agar (BBL, Maryland, USA). Culture plates were incubated for 18 to 24 hours at 33 to $37^{\circ}$ Celsius and examined for bacterial growth. Colony shape and pigmentation was described, as were zones of hemolysis and changes in color of the media. Colony types were inoculated onto Chocolate II, TSA II, or nutrient agar slants (BBL, Maryland, USA), incubated for 18 to 24 hours at 33 to $37^{\circ}$ Celsius, and stored at 2 to $8^{\circ}$ Celsius. On 1 September 1990 swabs, culture plates, and slants from the Pribilof Islands were transported to Moss Landing Marine Laboratories 
and refrigerated ( 2 to $8^{\circ}$ Celsius). Culture plates from Medny Island were incubated at 25 to $34^{\circ}$ Celsius for 24 hours and maintained at 2 to $8^{\circ}$ Celsius until shipment to Moss Landing Marine Laboratories on 8 September 1990.

\section{Identification of Bacteria}

Bacteria from the Chocolate II, TSA II, and nutrient agar slants were plated onto TSA II (BBL, Maryland, USA) and MacConkey II Agar (BBL, Maryland, USA) plates to observe hemolysis (production of clear, semi-clear, or greening zone in the media), swarming (growth in waves on media), colony pigmentation (color), and colony morphology (shape). Bacteria were stained using Gram reagents (BBL, Maryland, USA), and observed under a compound microscope to determine Gram reaction and cellular morphology. Gram negative rods were identified using the Minitek Miniaturized Differentiation System for the Identification of Enterobacteriaciae (BBL, Maryland, USA). Gram negative isolates were tested for possession of oxidase by placing Taxo N discs (BBL, Maryland, USA) on the MacConkey II Agar plates inoculated with bacteria, and the media was examined for a color change. Motility was determined by observing movement of bacteria in a hanging drop slide under a compound microscope. Bacterial cultures identified biochemically as Salmonella enteritidis were subsequently screened with the Salmonella Grouping Serum Set (BBL, Maryland, USA) to observe clumping. Positive reactions (clumps formed in solution on a slide) were then tested with group-specific (A-E) Salmonella antiserum (BBL, Maryland, USA). Three of 23 Salmonella cultures were randomly selected and submitted to Pathology Laboratory (Los Gatos, CA, USA) for independent identification.

Production of catalase was determined by adding bacteria to a drop of $3 \%$ hydrogen peroxide on a glass slide. Catalase positive (production of bubbles) cultures were tested for clumping factor by adding a drop of rabbit plasma to a suspension of bacteria on a glass slide 
and observed for clumping. Cultures that tested negative for bound clumping factor were used to inoculate tubes of rabbit plasma and incubated 4 to 24 hours at $37^{\circ}$ Celsius to observe clotting. Bacitracin discs (BBL, Maryland, USA) were placed on TSA II (BBL, Maryland, USA) inoculated with gram positive cocci (hemolytic, catalase negative) to observe inhibition of growth (Bacitracin sensitivity). A CAMP test was done by streaking a test organism across a TSA II (BBL, Maryland, USA) plate inoculated with B-toxin producing Staphylococcus aureus (BBL, Maryland, USA), and observed for an enhanced hemolyzed zone. Gram positive cocci were identified using the Minitek Miniaturized Differentiation System for the Identification of Gram Positive Cocci (BBL, Maryland, USA). Standard methods for identifying aerobic bacteria were followed (Jang et al. 1990).

\section{E. Statistical Analysis}

One way analysis of variance (ANOVA) was used to determine if there was a significant difference among rookeries of the Pribilof Islands in mean weight of males and females. Also, a Student's T-test (t-test) was used to determine if there was a significant difference between St. Paul and St. George Islands in mean weight of males and females. A Chi Square test was used to determine if there was a significant difference in frequencies of occurrence of species of pathogenic bacteria among rookeries, and number of males and females with a pathogenic bacterium. T-tests were used to determine if there was a significant difference in mean weight and mean index of condition for males and females with and without a pathogenic bacterium. An ANOVA was used to determine if there was a significant difference among rookeries in mean number of bacterial species and mean number of species of pathogenic bacteria per pup.

Thirty pups of St. Paul, St. George, and Medny Islands were sub-sampled randomly, and ANOVA was used to determine if there was a significant difference among 
islands in mean number of bacterial species and mean number of species of pathogenic bacteria per pup. A linear regression was used to determine if pup mortality (number of dead pups/number of live pups X 100; York and Fowler pers. com. 1990) and mean numbers of bacterial species and mean numbers of species of pathogenic bacteria per pup, and frequencies of occurrence of species of pathogenic bacteria were related for rookeries of the Pribilof and Medny Islands. Swartzman et al. (unpl. data 1987) reported few differences in pup density among rookeries, therefore, a linear regression was used to determine if number of live pups (York and Fowler pers. com. 1990), and mean numbers of bacterial species and mean numbers of species of pathogenic bacteria per pup, and frequencies of occurrence of species of pathogenic bacteria were related for rookeries of the Pribilof and Medny Islands. Also, a linear regression was used to determine if there was a relationship between prevalence (\%) of group-D Salmonella and pup mortality (\%) for the Vostochni, Gorbatch, Little Zapadni, Zapadni, and Zapadni Reef rookeries of St. Paul Island. A linear regression was used to determine if weight and index of condition of pups (Pribilof Islands only) and number of bacterial species, number of species of pathogenic bacteria per pup, and frequency of occurrence of species of pathogenic bacteria were related for rookeries of the Pribilof and Medny Islands. Frequency distributions were used to determine deviation from normality, and homogeneity of variance was tested using Cochran's test (Winer 1971). A Ryan-EinotGabriel-Welsch Q-test was used for posteriori multiple comparisons (Day and Quinn 1989). A 0.05 level of significance was used to test the null hypothesis for all statistical tests.

\section{RESULTS}

Pup weight was correlated positively with standard length, cranial width, index of fat thickness, and fore-flipper length for pups of the Pribilof Islands, and with standard length for pups of Medny Island (Table 1). There was no significant difference among rookeries of 
St. Paul, St. George, and Medny Islands in mean weight of male and female pups (Table 2). There was no significant difference between St. Paul and St. George Islands in mean weight of males and females. Therefore, males and females of the Pribilof Islands were combined and tested with pups of Medny Island. There was no significant difference between the Pribilof and Medny Islands in mean weight of male and female pups (Table 2).

Thirty-two taxa of bacteria were identified from ocular, pharyngeal, and rectal swabs (Table 3). Coliform (Escherichia, Klebsiella, Enterobacter, and Citrobacter ) and Proteus were the most common bacteria (Tables 4,5 , and 6). Five taxa of bacteria have been reported as pathogenic in Otariids (Table 7), and thus, were used for analysis of the effect of a pathogenic bacterium on pup weight and index of condition. Pups on the Reef rookery of St. Paul Island had the greatest number of species of pathogenic bacteria, and pups on the North and Zapadni rookeries of St. George Island the least $\left(\chi^{2}=45.223, P=0.0001\right)$. Group-D Salmonella was isolated from rectal swabs of pups on 5 rookeries of St. Paul Island only. Prevalence (\%) of group-D Salmonella was greater in female pups $\left(\chi^{2}=5.261\right.$, $\mathrm{P}=0.0218$ ) than male pups. Prevalence $(\%)$ of group-D Salmonella was correlated positively with pup mortality (\%) for the Little Zapadni, Zapadni, Zapadni Reef, Vostochni, and Gorbatch rookeries $\left(r^{2}=0.917, P=0.0105 ;\right.$ Fig. 2$)$. Mean weight ( 5 of 10 comparisons) and mean index of condition ( 3 of 10 comparisons) of males and females with a species of pathogenic bacterium isolated from rectal swabs was significantly less than mean weight and mean index of condition of male and female pups without a species of pathogenic bacterium (Table 8 and 9).

Pseudomonas aeruginosa was isolated from rectal, ocular, or pharyngeal swabs of pups on all rookeries of St. Paul Island, except the Zapadni rookery, from six pups on the East Cliffs rookery and one pup on the North rookery of St. George Island, and from three pups on the Urilie rookery of Medny Island (Tables 4, 5, and 6). There was no significant 
difference in frequency of isolation of Pseudomonas aeruginosa from rectal swabs of males and females $\left(\chi^{2}=0.133, P=0.715\right)$. Acinetobacter lwoffi was isolated from rectal, ocular, or pharyngeal swabs of pups on eight rookeries of St. Paul Island, and the East Cliffs and North rookeries of St. George Island (Tables 4, 5, and 6). Beta-hemolytic Streptococcus sp. and Staphylococcus aureus were isolated from ocular or pharyngeal swabs of pups on all rookeries (Tables 5 and 6).

Mean number of bacterial species per pup was significantly greater for pups on the Little Zapadni, Reef, Vostochni, Zapadni, and Morjovi rookeries, and mean number of species of pathogenic bacteria per pup was significantly greater for pups on the Reef rookery (Table 10). Comparisons among islands indicated mean number of bacterial species and mean number of species of pathogenic bacteria per pup were significantly greater for pups of St. Paul Island (Table 11) than Medny Island, but not St. George Island.

Linear regressions between pup mortality (\%) and number of live pups, and number of bacterial species and species of pathogenic bacteria were not significant (Table 12). Mean weight of pups was correlated positively with mean number of species of pathogenic bacteria per pup for rookeries of the Pribilof Islands and Medny Island (Table 13). The index of condition was correlated positively with number of bacterial species and number of species of pathogenic bacteria for pups of the Pribilof Islands (Table 13).

\section{DISCUSSION}

Comparisons between pup weight and total length, cranial width, index of fat thickness, and fore-flipper length were significant, but regression coefficients were low. This indicated sample size was adequate but variability in morphometric measurements was great. Pups were difficult to restrain, work was fast-paced, and weather was often harsh, all perhaps contributing to variability. There was no significant difference in mean weight of 
pups among rookeries and between the Pribilof and Medny Islands, indicating pups probably were of similar age at time of sampling. I believe the best measure of pup health was the index of condition because it incorporated weight, standard length, and the index of fat thickness. Ultra-sonic measurement of fat thickness (Gales and Burton 1987) may be a more reliable measure than the index of fat thickness, but this was not possible in the field due to the great number of pups sampled.

Coliform and Proteus were the most common bacteria in pharyngeal, ocular, and rectal swabs, which is not surprising because pinniped rookeries are contaminated heavily with feces. Mouths of pups contained fecal material, and obtaining uncontaminated pharyngeal swabs was difficult. Overall growth of bacteria was confluent on blood agar, and many beta-hemolytic colonies may have been missed. Pharyngeal swabs did not appear useful for the isolation of respiratory pathogens because of confluent growth of fecal contaminants.

Coliform bacteria were less abundant in ocular swabs than pharyngeal swabs, indicating eyes of pups were less contaminated with fecal material than mouths. Staphylococcus sp., Streptococcus sp., and Pseudomonas aeruginosa were isolated from ocular swabs, which may explain the presence of pups with exudate around eyes. Ocular infection with Pseudomonas aeruginosa, Staphylococcus, Streptococcus, and Neiserria is common in juvenile seals (Laukner 1985). In 1987, no diagnosis of ocular infection was made in pups of northern fur seals (Spraker unpl. data 1987). Therefore, the nictitating membrane of pups may be an efficient primary barrier to coliform, staphylococcal, streptococcal, and pseudomonad infection.

Escherichia coli was the most common bacteria in rectal swabs, and probably was part of the normal flora. Hookworm infection of pups was diagnosed at necropsy (Spraker unpl. data 1987) and may allow Coliform and Proteus to affect pups. An hemolytic E coli 
was cultured from my ocular swabs of pups on the Zapadni, Lukanin, and Tolstoi rookeries and from lungs of dead pups (Spraker pers. comm. 1991). This indicated hemolytic Escherichia coli may be an important pathogen in pups.

Five taxa of bacteria appeared to affect pup weight and index of pup condition. Pseudomonas sp. are distributed widely in soil and water (Washington 1985), and were isolated from pharyngeal and ocular swabs on almost all rookeries of the Pribilof and Medny Islands. Pseudomonas aeruginosa may be responsible for seal epizootics (Rand 1975) and is a frequent cause of bacteremia and pneumonia, especially in an immuno-supressed host (Washington 1985). $\underline{\mathrm{P}}$ aeruginosa was isolated from rectal swabs on six of 16 rookeries only, indicating $\mathrm{P}$ aeruginosa may not be part of the normal intestinal flora of northern fur seal pups. Recovery of $\mathrm{E}$ aeruginosa from male and female pups was not significantly different, indicating males and females encountered $\mathrm{P}$ aeruginosa with similar frequency.

$\underline{P}$ aeruginosa appeared to affect male pups only. Males may grow faster and have greater nutritional requirements than females (Costa and Gentry 1986). Infection of males by $\underline{\mathbf{P}}$ aeruginosa may depress growth rates by debilitating pups, resulting in significantly less weight and index of condition. Also, males may be more active than females, and consequently, experience more trauma from adults. This may increase prevalence (\%) of

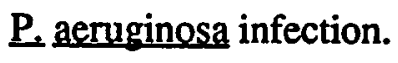

Acinetobacter lwoffi was isolated from rectal swabs of pups on the Reef rookery only, indicating $A$. lwoffi also may not be part of the normal intestinal flora of northern fur seal pups. Acinetobacter sp. were isolated from dead adult southern fur seals with enteritis (Baker and McCann 1989), and appeared to affect condition of male pups only. The behavioral differences between males and females discussed above may have increased exposure of male pups to A. Iwoffi. Acinetobacter sp. are free-living bacteria, which may explain the greater prevalence of $\underline{A}$ l lwoffi in pharyngeal and ocular swabs than in rectal 
swabs. A. lwoffi was isolated from rectal samples of apparently healthy northem fur seal pups of St. Paul Island (Keyes et al. 1981), but did not appear to affect condition of female pups. This indicated A. lwoffi probably was not pathogenic under normal circumstances.

Staphylococcus aureus was distributed among pups on most rookeries and probably did not affect growth of pups. S. aureus is the etiological agent of staphylococcal entercolitis (Jang et al. 1990), but determining the importance of $\underline{S}$ aureus as an enteric pathogen would require a greater number of swabs and diagnosis of pups.

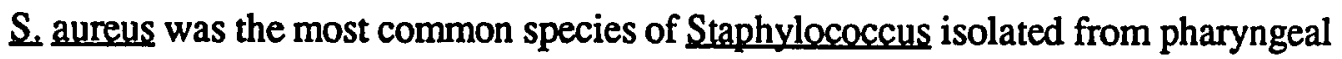
swabs, and is capable of causing respiratory disease in pinnipeds (Sweeney and Gilmartin 1974). At necropsy, Spraker (unpl. data 1987) diagnosed pneumonia in $8.9 \%$ of pups on St. Paul Island, and the prevalence (\%) in pharyngeal swabs indicated $\mathbf{S}$ aureus should be investigated as an etiological agent of pneumonia. Pasteurella sp. was isolated from terrestrial mammals with respiratory disease (Snipes et al. 1980), and from pups of northern fur seals (Keyes et al. 1968). Pasteurella sp. was not isolated from my swabs but should not be dismissed as an etiological agent of pneumonia.

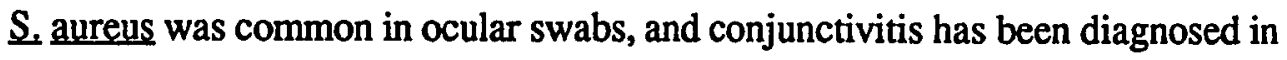
pups (Spraker pers. com. 1990). The prevalence of $\underline{S}$ aureus in ocular swabs indicated it should be considered potentially pathogenic. Cultures from live and freshly dead pups with conjunctivitis may determine the importance of $\underline{S}$. aureus as an ocular pathogen. No attempt was made to culture Chlamydia sp. from my ocular swabs and Chlamydia sp. may be an important ocular pathogen (Spraker pers. com. 1990)

Beta-hemolytic Streptococcus sp. (Streptococcus pyogenes and Streptococcus agalactiae) were infrequently isolated from pharyngeal and ocular swabs on almost all rookeries, and are pathogenic in pinnipeds (Laukner 1985). Streptococcus agalactiae is an 
important source of bovine mastitis, and affects mammary glands (Jang et al. 1990). Cultures of mammary glands from lactating females and mouths of pups may determine if S. agalactiae is transmitted from mother to pup during suckling. Infection of wounds by Streptococcus sp. is common in pinnipeds (Laukner 1985). Secondary bacterial infection of traumatic wounds was an important source of mortality for Antarctic fur seals (Baker and McCann 1989) and pups of northern fur seals (Keyes et al. 1975). The underdeveloped immune system in young animals (Baker and McCann 1989) and the prevalence (\%) of Streptococcus sp. may make pups susceptible to infection. Pneumococci have been identified as a major source of mortality in pinnipeds (Laukner 1985), but were not isolated in my swabs; their effect on northern fur seal pup mortality is unknown.

The most significant finding was group-D Salmonella in rectal swabs of pups on five rookeries of St. Paul Island. Stroud and Roelke (1980) isolated Salmonella enteritidis from two pups with a meningoencephalomyelitis of 175 dead pups examined on St. George Island. Keyes et al. (1981) reported no Salmonella sp. from dead pups of northern fur seals of St. Paul Island. Gilmartin et al. (1979) reported prevalence (33\%) of several Salmonella serotypes in apparently healthy pups of northern fur seals of the Channel Islands, and suggested Salmonella caused mild gastroenteritis only. In 1990, prevalence (\%) of group-D Salmonella on the Little Zapadni (20\%) and Zapadni Reef (26\%) rookeries of the Pribilof Islands were comparable to Gilmartin's study. Prevalence (\%) of group-D Salmonella was correlated positively with pup mortality (\%) for the Little Zapadni, Zapadni, Zapadni Reef, Vostochni, and Gorbatch rookeries. Thus, group-D Salmonella may have affected pup mortality (\%) on these rookeries before sampling.

Mean weight of males and females with group-D Salmonella was significantly less than males and females without group-D Salmonella, indicating group-D Salmonella may have affected weight gain of pups. Nutritionally-stressed pups may be more susceptible to 
infection by group-D Salmonella, and pup mortality may be greater in pups of lower weight with group-D Salmonella. Prevalence (\%) of group-D Salmonella was greater in female pups. Females are generally smaller in size than males (Lander 1979) and may not be as active. If females remain in contact with sources of group-D Salmonella for a greater amount of time than males, they may be more vulnerable to infection. Group-D Salmonella appeared to affect the index of condition for females only, indicating group-D Salmonella may have a greater effect on the growth of females than males. Males may enter water before females, and this may wash sources of group-D Salmonella from male pups. It is interesting three of five rookeries where group-D Salmonella was isolated are located in a bay used frequently by large fishing vessels. If sources of group-D Salmonella are discharged from these vessels and wash ashore, pups may become infected.

Calambokidis and Gentry (1985) reported tagged pups that died weighed less at birth than the weight at birth of the total marked population, and pups that died of infectious disease weighed less at birth than the average weight at birth. In 1990, mean weight ( 5 of 10 comparisons) and index of condition ( 3 of 10 comparisons) of my pups with a pathogenic bacterium were significantly less than pups without these pathogenic bacteria. Weight and index of condition of pups with pathogenic bacteria may have been affected by timing and susceptibility to infection. Infection of pups with relatively normal weight and condition at birth may prevent weight gain and growth. Alternatively, pups of relatively low birth weight and condition may be more susceptible to infection, and pups of lower weight and condition with pathogenic bacteria may have greater mortality than pups without these bacteria. The index of condition seemed less sensitive to the effects of bacteria, indicating most pathogenic bacteria may have affected weight and not growth.

Number of bacterial species and number of species of pathogenic bacteria per pup increased with the index of condition (Pribilof Islands only), and not weight of pups. Large 
pups may be more mobile than small pups, and behavioral differences may have exposed larger pups to a greater number of species of bacteria. The positive slopes of the regression lines indicated most bacteria did not affect the health of pups at time of sampling.

Comparisons among rookeries indicated pups on the Little Zapadni, Zapadni, Reef, Vostochni, and Morjovi rookeries of St. Paul Island had a significantly greater mean number of bacterial species and the Gorbatch and Kitovi rookeries of St. Paul Island the least. Number of live pups were relatively greater for the Little Zapadni, Zapadni, Reef, and Vostochni rookeries, but did not appear related to mean number of bacterial species per pup. Thus, bacterial diversity (number of species per pup) was not affected by number of live pups on rookeries. Although, there was no significant relationship between pup mortality (\%) and mean number of bacterial species per pup, pup mortality (\%) on the Little Zapadni, Zapadni, and Reef rookeries was greater than the average pup mortality (\%) of St. Paul Island, and pup mortality (\%) on the Kitovi and Gorbatch rookeries was less than the average pup mortality (\%) of St. Paul Island.

Mean number of species of pathogenic bacteria per pup and frequency of occurrence of species of pathogenic bacteria were significantly greater for the Reef rookery of St. Paul Island and the East rookery of St. George Island. Pup mortality (\%) for the Reef rookery was greater than the average pup mortality (\%) of St. Paul Island, but did not appear related to mean number of species of pathogenic bacteria per pup, or frequency of occurrence of species of pathogenic bacteria.

Comparisons among islands indicated pups on St. Paul Island had a greater mean number of bacterial species per pup and mean number of species of pathogenic bacteria per pup than Medny Island, but not St.George Island. Pups on islands with a greater number of animals (St. Paul Island) may have been exposed to a greater number of bacteria. The greater mean number of bacterial species and mean number of species of pathogenic bacteria per pup 
for St. Paul Island, may have contributed to the greater average pup mortality (\%) of St. Paul Island than St. George Island and Medny Island.

\section{SUMMARY}

Most bacteria isolated from pups of northern fur seals could be capable of causing disease in a compromised host, but many pups appeared healthy at time of sampling. Therefore, bacteria probably did not affect most pups. Pups become stressed nutritionally, traumatized, and exposed to extremely harsh weather which may have allowed bacteria to affect the health of pups after sampling. Few bacteria isolated were reported etiological agents of mass pinniped deaths, and for the Pribilof Islands, numbers of pathogenic species of bacteria and pup mortality (\%) were not related. Pseudomonas aeruginosa, Acinetobacter lwoffi, Streptococcus pyogenes, Streptococcus agalactiae, Staphylococcus aureus, Escherichia coli-hemolytic, and group-D Salmonella were isolated from pups and probably are associated with morbidity and mortality. Prevalence (\%) of group-D Salmonella was greatest for pups on the Little Zapadni, Zapadni, and Zapadni Reef rookeries of St. Paul Island, and may have contributed to greater pup mortality for these rookeries than the average island mortality. Diagnosis of pups on the Reef, Zapadni, Zapadni Reef, and Little Zapadni rookeries of St. Paul Island would be valuable and for these rookeries and pup mortality should be examined in the future.

Comparisons among rookeries indicated pups on the Little Zapadni, Zapadni, Reef, Vostochni, and Morjovi rookeries of St. Paul Island had a significantly greater mean number of bacterial species and the Gorbatch and Kitovi rookeries of St. Paul Island the least. Number of live pups was relatively greater for the Little Zapadni, Zapadni, Reef, and Vostochni rookeries, but did not affect bacterial diversity. Although there was no significant relationship between pup mortality (\%) and mean number of bacterial species per pup, pup 
mortality (\%) on the Little Zapadni, Zapadni, and Reef rookeries was apparently greater than the average pup mortality of St. Paul Island. Pup mortality (\%) on the Kitovi and Gorbatch rookeries was apparently less than the average pup mortality (\%) of St. Paul Island.

Pups on St. Paul Island had a significantly greater number of species of pathogenic bacteria than Medny Island but not St. George Island. The greater number of animals on St. Paul Island may represent a greater source of pathogenic bacteria. Pups of St. Paul Island had a significantly greater number of bacterial species and greater number of species of pathogenic bacteria which may contribute to the greater average island pup mortality (\%).

Comparisons between pup mortality (\%), number of live pups, weight and index of condition of pups, and number of bacterial species, and number of species of pathogenic bacteria were not significant, indicating most bacteria did not affect pup health and mortality. Bacteria may affect pup mortality when associated with traumatic, nutritional, or environmental stress. The wide distribution of bacteria in pups from all rookeries indicated pups are exposed to many of the same bacteria. The physiological state of pups may determine the effects of bacteria on pup health. Crowded, nutritionally-stressed pups may be more susceptible to invasion by pathogenic and opportunistically pathogenic bacteria, and pup mortality may be greater in pups of lower weight infected with a pathogenic bacteria. At this time, differential pup mortality (\%) among most rookeries cannot be explained by bacteria isolated from pups.

This survey of bacteria indicated group-D Salmonella was the most important potential pathogen. Prevalence (\%) of group-D Salmonella was correlated positively with pup mortality (\%) for the Little Zapadni, Zapadni, Zapadni Reef, Vostochni, and Gorbatch rookeries, indicating group-D Salmonella may increase pup mortality. Female pups appeared affected by group-D Salmonella more than male pups. If group-D Salmonella increases mortality of female pups, fewer pups would be born in subsequent years, which may prevent 
increases in numbers of northern fur seals on the Little Zapadni, Zapadni, Zapadni Reef, Vostochni, and Gorbatch rookeries of St. Paul Island. 


\section{ACKNOWLEDGMENTS}

My thesis could not have been completed without James T. Harvey, George A. Antonelis, Mike Foster, and Kurt Snipes. Dr. Harvey was part the entire project, and most importantly, he motivated me to do the best job I could; thanks Jim. George Antonelis collected field samples on Medny Island (USSR) and his expertise improved this manuscript. Mike Foster provided reviews, and importantly, attitude adjustment in Baja; think about it-. Dr. Kurt Snipes provided reviews and supported my bacteriology. Also, his expertise assured others members of my committee that I was OK; thanks Kurt.

I thank Anne York who was instrumental in coordinating the great amount of field work for this project. I thank Jason Baker, Rolph Ream, Bruce Robson, Mauricio Lima, Enrique Paez, Alejandro Malek, and Jessica Rykken for their valuable field assistance. Terry Spraker from the College of Veterinary Medicine, Colorado State University, provided expert technical advice, and generously allowed me access to his extensive data on causes of fur seal pup mortality. Also, he supported my ideas for further education.

The students and faculty of Moss Landing Marine Laboratories were invaluable to my education and research. Most importantly, I thank John Mason, Patience Browne, Steve Trumble, and Dan Bockus from Moss Landing Marine Laboratories for field assistance.

I thank the National Marine Mammal Laboratory (Tom Loughlin and George Antonelis), the Dr. Earl Myers and Ethyl Myers Oceanographic and Marine Biology Trust, and the Student Packard Fund for financial support.

I thank my brother and sisters, Chris, Susan, and Molly, Grandma Whealen, and Grandma and Grandpa Hall, who in many ways provided support. This thesis is dedicated to Andy and Mary Burd; I could not have completed it without you both, thank you. 


\section{LITERATURE CITED}

Anderson, R. M., and R. M. May. 1979. Population biology of infectious diseases: Part I and II. Nature 280: 361-67.

Baker, J. R., and T. S. McCann. 1989. Pathology and bacteriology of adult male Antarctic fur seals, Arctocephalus gazella, dying at Bird Island, South Georgia. Brit. Vet. Jour. 145: 263-275.

Briggs, L. 1990. Distribution of adult territorial males and pups born on St. Paul and St. George Islands. In Fur Seal Investigations, 1987 and 1988. Edited by H. Kajimura Tech. Memo. NMFS F/NWC Nat. Mar. Mamm. Lab., Northw. Alaska Fish. Cent., Natl. Mar. Fish. Serv., NOAA, Seattle, WA 98115-0070. pp. 66-84.

Calambokidis, J., and R. L. Gentry. 1985. Mortality of northern fur seal pups in relation to growth and birth weights. J. of Wildl. Dis. 21(3): 327-330.

Chapman, D. G., and A. M. Johnson. 1968. Estimation of fur seal pup populations by randomized sampling. Trans. Am. Fish. Soc. 97(3): 264-270.

Craig, A. M. 1964. Histology of reproduction and the estrus cycle in the female fur seal, Callorhinus ursinus. J. Fish. Res. Bd. Canada. 21(4): 773-811.

Cosby, S. L., McQuaid, S., Duffy, N., Lyons, C., Rima, B. K., Allan, G. M., McCullough, S. J., Kennedy, S., Smyth, J.A., McNeilly, F., and C. Craig. 1988. Characterization of seal morbillivirus. Nature 336: 115-116.

Costa, D. P., and R. L. Gentry. 1986. Free-ranging energetics of northern fur seals. In Maternal Strategies on Land and at Sea. Edited by R.L. Gentry and G.L. Kooyman. Princeton University Press, Princeton, New Jersey. p. 96.

Day, R. W., and G. P. Quinn. 1989. Comparisons of treatments after and analysis of variance in ecology. Ecological Monographs 59(4): 433-463. 
Fowler, C. W. 1984. Density dependence in northern fur seals (Callorhinus ursinus). Paper presented in Cambridge England, April, 1984. Symposium on Fur Seals of the World.

1985. An evaluation of the role of entanglement in the population dynamics of northem fur seals on the Pribilof Islands. In Proceedings of the Workshop on the Fate and Impact of Marine Debris. 27-29 November 1984, Honolulu, Hawaii, Edited by R. S. Shomura, and H. O. Yoshida. NOAA Tech. Memo. NOAA-TM NMSF-SWFC-54. pp. 291-307. 1987 Marine debris and northern fur seals: a case study. Mar. Pollut. Bull. 18(6B): 326-335.

Gales, N. J., and H. R. Burton. 1987. Ultrasonic measurement of blubber thickness of the southern elephant seal, Mirounga leonia (Linn.). Australian Journal of Zoology 35: 207-217.

Gentry, R. L., and J. R. Holt. 1986. Attendance Behavior of Northern Fur Seals, In Fur Seal: Maternal strategies on Land and Sea. Edited by R.L. Gentry and G.L. Kooyman. Princeton University Press, Princeton, New Jersey. pp. 291.

Gentry, R. L., and J. H. Johnson. 1981. Predation by sea lions on northern fur seal neonates. Mammalia 45: 423-430.

Gilmartin, W. G., P. Vainik, and V. Neill. 1979. Salmonellae in feral pinnipeds off the Southern California Coast. J. Wildl. Dis. 15: 511-514.

Harwood, J., and Greenfell, B. 1990. Long term risks of recurrent seal plagues. Mar. Pol. Bull. 21: 284-287.

Jang, S., E. L. Biberstein, and D. C. Hirsh. 1990. A Diagnostic Manual of Veterinary Clinical Bacteriology and Mycology. University of Califomia, Davis. Reprinted by California State University, San Jose, CA. 
Jellison, W. L., and K. C. Milner. 1958. Salmonellosis (bacillary dysentery) of fur seals. J. Wild. Mgmnt. 22: 199-200.

Kenyon, K. W., V. B. Scheffer, and D. G. Chapman. 1954. A Population Study of the Alaska fur-seal herd. U. S. Fish Wildl. Serv., Spec. Sci. Rep. Wildl. 12. p. 7.

Keyes, M. C. 1965. Pathology of the northern fur seal. J. Am. Vet. Med. Ass. 147: 1091-1095.

Keyes, M. C., F. W. Crews, and J. R. Ross. 1968. Pasteurella multocida from a california sea lion (Zalophus californianus). J. Amer. Vet. Med. Assoc. 153: 803-804.

Keyes, M. C., K. C. Ke, M. D. Dailey, and N. A. Vedros. 1981. Veterinary Medical Services and Research. In Fur Seal Investigations. NWAFC Processed Report 812. Northw. Alaska Fish. Cent., Natl. Mar. Fish. Serv., NOAA, Seattle, WA 981150070. pp.33-36.

Keyes, M. C., A. W. Smith, N. A. Vedros, T. G. Akers, and K. C. Kim. 1975. Physiology and Medicine. In Fur Seal Investigations. Mar. Mammal Div., Northw. Alaska Fish. Cent., Natl. Mar. Fish. Serv., NOAA, Seattle, WA 98115-0070. pp. 43-48.

Lack, D. 1954. The Natural Regulation of Animal Numbers. Oxford University Press. In May, R. M., and R. M. Hassel. 1979. Population biology of infectious disease: Part II. Nature 280: 455-461.

Lander, R. H. 1979. Role of land and ocean mortality in yield of male Alaskan fur seal, Callorhinus ursinus. Fishery Bulletin 77(1-2): 311-314. . 1979. Alaskan or Northern Fur Seal. Vol. 2, In Mammals in the Sea. Pinniped Species. Summaries and Reports on Sirenians, Food Agric. Organ. U.N. Rome, FAO Fish Ser. 5. pp. 19-23. 
1980. Summary of Northern Fur Seal Data and Collection Procedures.

Vol. 1, Land Data of the United States and Soviet Union (excluding tag and recovery records). NOAA Tech. Memo. NMSF F/NWC-3, Natl. Mar. Mammal Lab., Northw. Alaska Fish. Serv., NOAA, Seattle WA. 98115-0070. pp. 315

Lander, R. H., and H. Kajimura. 1976. Status of northern fur seals. Advisory Committee on Marine Resources Research, Scientific Consultation on Marine Mammals. 31 August 1976. Bergen, Norway.

Laukner, G. 1985. Diseases of Mammalia: Pinnipedia. Vol 4, In Diseases of Marine Animals. Edited by Otto Kinne. Westholsteinische Verlagsdruckerie Boyens \& Co., GDR. pp. 683-709.,

Loughlin, T. R., L. Consiglieri, R. L. DeLong, and A. T. Actor. 1983. Incidental catch of marine mammals by foreign fishing vessels, 1978-81. Mar. Fish. Rev. 45(7-9): 44-49.

Loughlin, T. R., J. L. Bengston, and R. L. Merrick. 1986. Characteristics of feeding trips of female northern fur seals. Can. J. Zool. 65: 2079-2084.

Loughlin, T. R. 1989. Status of Northern Fur Seals. Outer Continental Shelf Environmental Assessment Program. Gulf of Alaska, Cook Inlet, and North Aleution Basin Information Update Meeting. 7-8 February, Anchorage, Alaska USDC/USDI, OCS Study, MMS 89-0041.

Peterson, R. S. 1965. Behavior of the Northern Fur Seal (Ph.D. Thesis), Baltimore, John Hopkins University. pp. 214. 1968. Social Behavior of Pinnipeds with particular reference to the Northern Fur Seal: The Behavior and Physiology of Pinnipeds. Meredith Corporation, New York, New York. pp. 3-53. 
Rand, C. S. 1975. Nodular suppurative cutaneous cellulitis in a Galapagos sea lion. J. Wildl. Dis. 11: 325-329.

Scheffer, V. B., C. H. Fiscus, and E. I. Todd. 1984. History of Scientific Study and Management of the Alaskan Fur Seal, Callorhinus ursinus, 1786-1964. NOAA Tech. Memo. NMFS SSRF-780, NOAA/ NMFS, Seattle, WA 98115-0070.

Smith, A.W., Brown, R. J., Skilling, D. E., Bray, H. L., and M. C. Keyes. 1977. Naturally-occurring leptospirosis in northern fur seals (Callorhinus ursinus). J. Wildl. Dis. 13: 145-148.

Snipes, K. P., E. L. Biberstein, and M. E. Fowler. 1980. A Pasteurella sp. associated with respiratory disease in captive desert tortoises. J. Amer. Vet. Med. Assoc. 177: 804-807.

Spraker, T. 1987. Summary of causes of fur seal pup mortality on St. Paul Island, AK. National Marine Mammal Laboratory, National Marine Fisheries Service, Seattle, WA 98115-0070.

. 1990. Telephone conversation with author.

1991. Conversation with author.

Stroud, R. K., and M. D. Dailey. 1978. Parasites and associated pathology observed in pinnipeds stranded along the Oregon coast. J. Wildl. Dis. 14: 292-298.

Stroud R. K., and M. E. Roelke. 1980. Salmonella meningoencephalomyelitis in a northern fur seal (Callorhinus ursinus). J. Wildl. Dis. 16(1): 15-18.

Stroud, R. K., and T. J. Roffe. 1979. Causes of death in marine mammals stranded along the Oregon Coast. J. Wildl. Dis. 15: 91-97.

Swartzman, G., R. S. Manasse, and C. Huang. 1987. Fur seal rookery pup-area and harem bull-area relationships. National Marine Mammal Laboratory, National Marine Fisheries Service, Seattle, WA 98115-0070. 
Sweeney, J. C., and W. G. Gilmartin. 1974. Survey of diseases in free-living California sea lions. J. Wildl. Dis. 10: 370-376.

York, A. E. 1987. Northem fur seal, Callorhinus ursinus, Eastern Pacific Population (Pribilof Islands, Alaska and San Miguel Island, California). In Status, Biology and Ecology of Fur Seals. Edited by J. P. Crozall and R. L. Gentry. Proc. of an International Symposium and Workshop, Cambridge, England, 23-27 April 1984. NOAA Tech. Mem. NMSF 51. pp. 9-21.

. 1990. Trends in Numbers of Pups Born on St. Paul and St. George Islands, 1973-88. In Fur Seal Investigations, 1987 and 1988. Edited by H. Kajimura. NOAA Tech. Mem. NMFS F/NWC-180. pp. 31-37.

York, A. E., and G. A. Antonelis. 1988. Northern Fur Seal Pups Born on St. Paul Island, 1987-88. In Fur seal investigations 1987 and 1988. Edited by H. Kajimura. NOAA Tech. Mem. NMSF F/NWC-180. pp. 16-30.

York, A. E., and C. W. Fowler. 1990. Letter to author.

York, A. E., and P. Kozloff. 1987. On the estimation of numbers of Northern Fur Seal, Callorhinus ursinus pups born on St. Paul Island, 1980-86. Fish. Bull. 85 (2): 367-375.

Waldorf, A., and N. A. Vedros. 1978. Northern fur seal, Callorhinus ursinus, the skin and fatty acid as a natural barrier to fungal penetration. Aquat. Mamm. 6: 77-89.

Washington, J. A. 1985. Laboratory Procedures in Clinical Microbiology, SpringerVerlag, NY, NY, 10010.

Wilson, T. M., and P. R. Sweeney. 1970. Morphological studies of seal-pox virus. J. Wildl. Dis. 6: 155-159.

Winer, B. J. 1971. Statistical Principles in Experimental Design. Second Edition McGrawHill, Inc. 
Table 1. Linear regressions of weight $(\mathrm{kg})$ with standard length $(\mathrm{cm})$, cranial width $(\mathrm{cm})$, index of fat thickness $(\mathrm{cm})$, and fore-flipper length $(\mathrm{cm})$ for northern fur seal pups on the Pribilof Islands and Medny Island.

\begin{tabular}{|c|c|c|c|c|}
\hline & $\mathbf{n}$ & $\begin{array}{l}\text { REGRESSION } \\
\text { COEFFICIENT }\end{array}$ & $\begin{array}{c}\text { F } \\
\text { VALUE }\end{array}$ & $\begin{array}{c}\mathrm{P} \\
\text { VALUE }\end{array}$ \\
\hline \multicolumn{5}{|l|}{$\begin{array}{l}\text { ST. PAUL } \\
\text { MALES AND FEMALES }\end{array}$} \\
\hline STANDARD LENGTH & 360 & 0.754 & 471.035 & 0.0001 \\
\hline CRANIAL WIDTH & 360 & 0.609 & 210.515 & 0.0001 \\
\hline FAT PINCH & 360 & 0.466 & 99.447 & 0.0001 \\
\hline FORE-FLIPPER LENGTH & 360 & 0.577 & 178.937 & 0.0001 \\
\hline \multicolumn{5}{|l|}{ MALES } \\
\hline STANDARD LENGTH & 180 & 0.732 & 205.254 & 0.0001 \\
\hline CRANIAL WIDTH & 180 & 0.569 & 85.117 & 0.0001 \\
\hline FAT PINCH & 180 & 0.527 & 68.357 & 0.0001 \\
\hline FORE-FLIPPER LENGTH & 180 & 0.534 & 70.875 & 0.0001 \\
\hline \multicolumn{5}{|l|}{ FEMALES } \\
\hline STANDARD LENGTH & 180 & 0.657 & 135.057 & 0.0001 \\
\hline CRANIAL WDTH & 180 & 0.511 & 62.873 & 0.0001 \\
\hline FAT PINCH & 180 & 0.412 & 36.424 & 0.0001 \\
\hline FORE-FLIPPER LENGTH & 180 & 0.474 & 51.529 & 0.0001 \\
\hline \multicolumn{5}{|l|}{$\begin{array}{l}\text { ST. GEORGE } \\
\text { MALES AND FEMALES }\end{array}$} \\
\hline STANDARD LENGTH & 90 & 0.662 & 68.644 & 0.0001 \\
\hline CRANIAL WIDTH & 90 & 0.463 & 24.034 & 0.0001 \\
\hline FAT PINCH & 90 & 0.449 & 22.161 & 0.0001 \\
\hline FORE-FLIPPER LENGTH & 90 & 0.166 & 2.487 & 0.1184 \\
\hline \multicolumn{5}{|l|}{ MALES } \\
\hline STANDARD LENGTH & 45 & 0.678 & 35.79 & 0.0001 \\
\hline CRANIAL WIDTH & 45 & 0.481 & 12.543 & 0.0001 \\
\hline FAT PINCH & 45 & 0.517 & 15.327 & 0.0003 \\
\hline FORE-FLIPPER LENGTH & 45 & 0.052 & 0.116 & 0.7354 \\
\hline \multicolumn{5}{|l|}{ FEMALES } \\
\hline STANDARD LENGTH & 45 & 0.505 & 15.072 & 0.0003 \\
\hline CRANIAL WIDTH & 45 & 0.271 & 3.486 & 0.0686 \\
\hline FAT PINCH & 45 & 0.395 & 8.112 & 0.0067 \\
\hline FORE-FLIPPER LENGTH & 45 & 0.445 & 10.876 & 0.0019 \\
\hline \multirow{2}{*}{\multicolumn{5}{|c|}{$\begin{array}{l}\text { MEDNY } \\
\text { MALES AND FEMALES }\end{array}$}} \\
\hline & & & & \\
\hline $\begin{array}{l}\text { STANDARD LENGTH } \\
\text { MALES }\end{array}$ & 31 & 0.888 & 108.047 & 0.0001 \\
\hline $\begin{array}{l}\text { STANDARD LENGTH } \\
\text { FEMALES }\end{array}$ & 16 & 0.865 & 38.655 & 0.0001 \\
\hline STANDARD LENGTH & 15 & 0.892 & 54.436 & 0.0001 \\
\hline
\end{tabular}


Table 2. Comparison of mean weight $(\mathrm{kg})$ of males and females among rookeries using ANOVA, and between islands using Student's t-test, for northern fur seal pups of St. Paul, St. George, and Medny Islands.

\begin{tabular}{lclc}
\hline & n & $\begin{array}{l}\text { TEST } \\
\text { STATISTIC }\end{array}$ & VALUE \\
\hline AMONG ROOKERIES OF ST. PAUL & 180 & $\mathrm{~F}=0.711$ & 0.7267 \\
MALES & 180 & $\mathrm{~F}=1.392$ & 0.1806 \\
FEMALES & & & \\
AMONG ROOKERIES OF ST. GEORGE & 45 & $\mathrm{~F}=2.965$ & 0.0625 \\
MALES & 45 & $\mathrm{~F}=1.768$ & 0.1832 \\
FEMALES & & & \\
BETWEEN ST. PAUL AND ST. GEORGE & 225 & $\mathrm{t}=1.061$ & 0.2897 \\
MALES & 225 & $\mathrm{t}=0.305$ & 0.7605 \\
FEMALES & & & \\
BETWEEN PRIBILOF AND MEDNY & 240 & $\mathrm{t}=0.693$ & 0.4889 \\
MALES & 240 & $\mathrm{t}=0.658$ & 0.5111 \\
FEMALES & & &
\end{tabular}


Table 3. Bacteria isolated from swabs of northem fur seal pups of the Pribilof Islands and Medny Island.

\begin{tabular}{|c|c|c|c|}
\hline \multirow[b]{2}{*}{ BACTERIUM } & \multicolumn{3}{|c|}{ TYPE OF SWAB } \\
\hline & RECTAL & OCULAR & PHARYNGEAL \\
\hline Acinetobacter Iwoffi & $\mathbf{X}$ & $\mathrm{X}$ & $\mathrm{X}$ \\
\hline Citrobacter freundii & $\mathbf{X}$ & $\mathrm{X}$ & $\mathrm{x}$ \\
\hline Enterobacter cloacae & $\mathrm{x}$ & $\mathrm{X}$ & $\mathrm{x}$ \\
\hline Enterobacter aerogenes & $\mathrm{x}$ & $\mathrm{X}$ & $\mathrm{x}$ \\
\hline Escherichia coli & $\mathbf{X}$ & $\mathrm{X}$ & $\mathrm{X}$ \\
\hline Hafnia alvei & $\mathrm{x}$ & & \\
\hline Klebsiella oxytoca & $\mathrm{X}$ & $\mathrm{X}$ & $\mathrm{X}$ \\
\hline Micrococcus sp. & & $\mathrm{X}$ & $\mathrm{X}$ \\
\hline Morganella morganii & $\mathrm{X}$ & & \\
\hline Proteus mirabilis & $\mathrm{X}$ & $\mathrm{X}$ & $\mathrm{X}$ \\
\hline Proteus vulgaris & $\mathrm{x}$ & $\mathrm{x}$ & $\mathrm{x}$ \\
\hline Pseudomonas aeruginosa & $\mathrm{X}$ & $\mathrm{x}$ & $\mathrm{X}$ \\
\hline Group-D Salmonella & $\mathrm{x}$ & & \\
\hline Serratia marcescens & $\mathrm{X}$ & & \\
\hline Staphylococcus aureus & $x$ & $\mathrm{x}$ & $x$ \\
\hline Staphylococcus chonii & & $\mathrm{X}$ & \\
\hline Staphylococcus epidermidis & & $\mathrm{X}$ & $\mathrm{x}$ \\
\hline Staphylococcus hyicus & & $\mathrm{X}$ & $\mathrm{X}$ \\
\hline Staphylococcus simulans & & $\mathrm{X}$ & \\
\hline Staphylococcus warneri & & $\mathrm{X}$ & $\mathrm{X}$ \\
\hline Staphylococcus xylosus & & $\mathrm{X}$ & $\mathrm{X}$ \\
\hline Streptococcus acidominimus & & $x$ & $\mathrm{X}$ \\
\hline Streptococcus agalactiae & & $\mathrm{x}$ & $\mathrm{x}$ \\
\hline Streptococcus avium & & $\mathrm{X}$ & $\mathrm{X}$ \\
\hline Streptococcus bovis & & $\mathrm{X}$ & $\mathrm{x}$ \\
\hline Streptococcus faecalis & & $\mathrm{X}$ & $\mathrm{x}$ \\
\hline Streptococcus mitis & & $\mathrm{X}$ & $\mathrm{X}$ \\
\hline Streptococcus morbillorium & & $\mathrm{X}$ & \\
\hline Streptococcus mutans & & $\mathrm{x}$ & $\mathrm{X}$ \\
\hline Streptococcus pyogenes & $\mathrm{x}$ & $\mathrm{X}$ & $\mathrm{X}$ \\
\hline Streptococcus sanguis & & $\mathrm{X}$ & \\
\hline Streptococcus uberis & & $\mathrm{X}$ & $\mathrm{X}$ \\
\hline
\end{tabular}




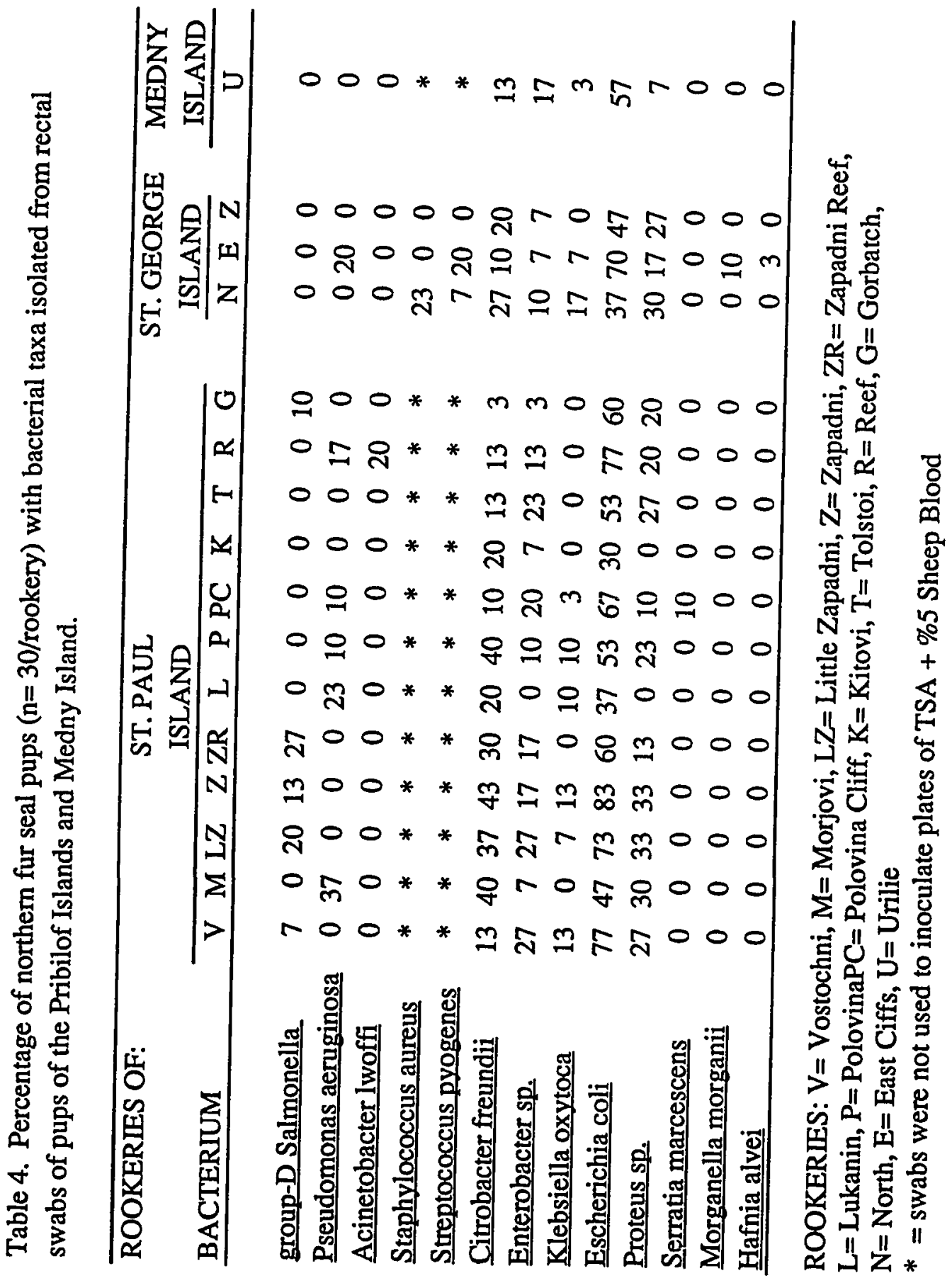




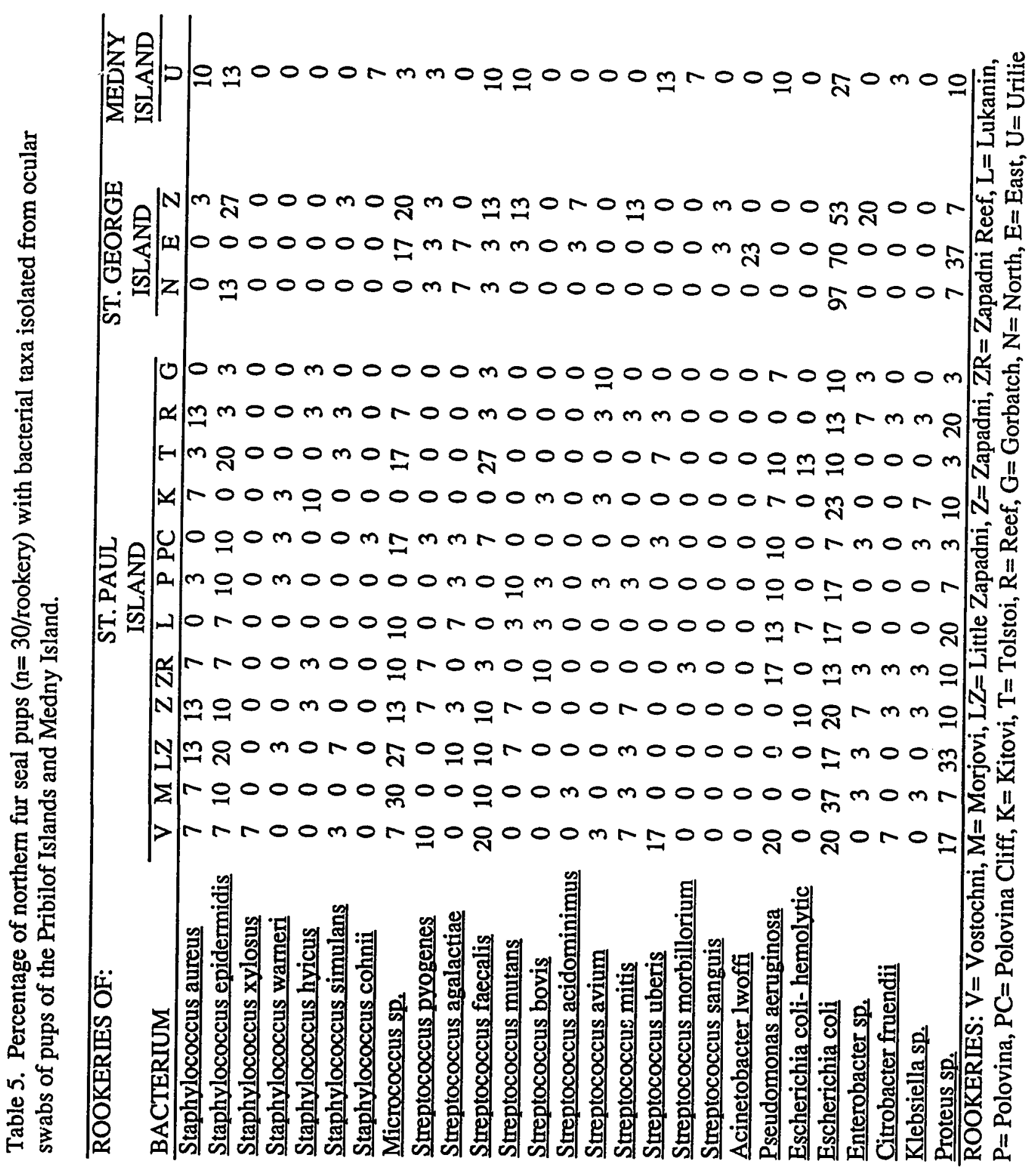




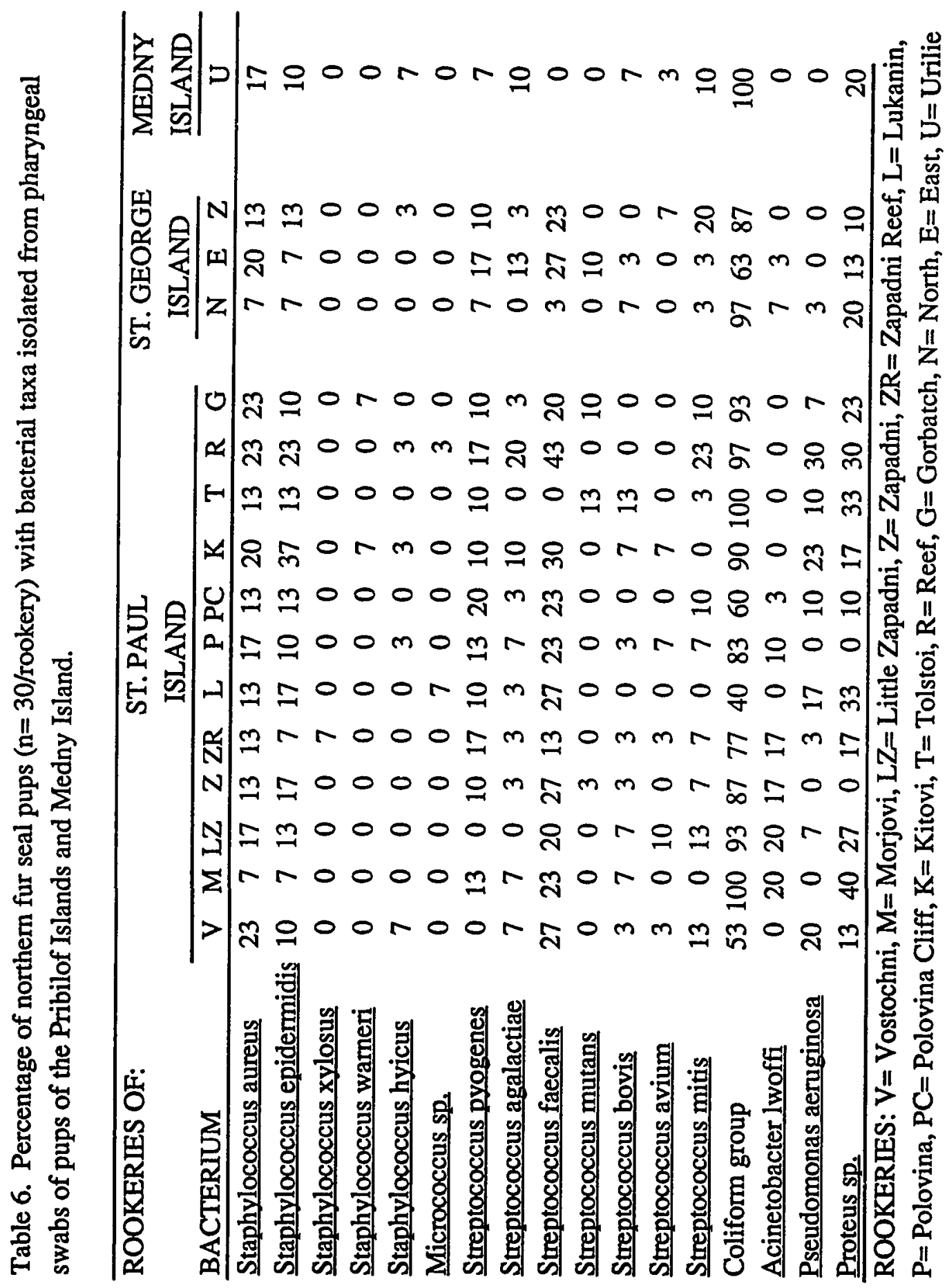


Table 7. Bacteria reported as pathogenic in Otariids.

\begin{tabular}{lll}
\hline & ORGAN & \\
BACTERIUM & SYSTEM AFFECTED & REFERENCE \\
\hline Salmonella sp. & gastrointestinal & Jellison and Milner 1958, \\
& pulmonary & Sweeney and Gilmartin 1974 \\
Pseudomonas sp. & pulmonary & Sweeney and Gilmartin 1974 \\
Staphylococcus aureus & pulmonary & Sweeney and Gilmartin 1974 \\
Streptococcus sp. & pulmonary & Baker and McCann 1989 \\
Acinetobacter lwoffi & gastrointestinal, pulmonary & Baker and McCann 1989 \\
\hline
\end{tabular}


Table 8. Comparison of mean weight (kg) of northem fur seal pups with and without a species of pathogenic bacterium isolated from rectal swabs using a Student's t-test.

\begin{tabular}{|c|c|c|c|c|c|}
\hline BACTERIUM & SEX & $\mathbf{n}$ & $\begin{array}{c}\text { MEAN } \\
\text { WEIGH } \\
(\mathrm{kg})\end{array}$ & SD & $\begin{array}{c}\mathrm{P} \\
\text { VALUE }\end{array}$ \\
\hline group-D Salmonella & male & 6 & 7.46 & 1.35 & 0.0002 \\
\hline no group-D Salmonella & male & 69 & 9.83 & 1.45 & \\
\hline group-D Salmonella & female & 17 & 7.39 & 1.01 & 0.0026 \\
\hline no group-D Salmonella & female & 58 & 8.58 & 1.46 & \\
\hline Pseudomonas aeruginosa & male & 16 & 7.80 & 1.10 & 0.0001 \\
\hline no Pseudomonas aeruginosa & male & 74 & 10.00 & 1.95 & \\
\hline Pseudomonas aeruginosa & female & 19 & 8.32 & 1.04 & 0.2390 \\
\hline no Pseudomonas aeruginosa & female & 71 & 8.05 & 1.41 & \\
\hline Acinetobacter lwoffi & male & 4 & 8.31 & 1.39 & 0.0092 \\
\hline no Acinetobacter lwoffi & male & 11 & 11.20 & 1.68 & \\
\hline Acinetobacter lwoffi & female & 2 & 7.13 & 0.53 & 0.0689 \\
\hline no Acinetobacter lwoffi & female & 13 & 8.94 & 1.25 & \\
\hline Streptococcus pyogenes & male & 2 & 10.00 & 1.41 & 0.6941 \\
\hline no Streptococcus pyogenes & male & 13 & 9.55 & 1.57 & \\
\hline Streptococcus pyogenes & female & 7 & 8.32 & 1.21 & 0.9446 \\
\hline no Streptococcus pyogenes & female & 23 & 8.36 & 1.24 & \\
\hline Staphylococcus aureus & male & 4 & 9.69 & 2.15 & 0.3643 \\
\hline no Staphylococcus aureus & male & 11 & 8.77 & 1.49 & \\
\hline Staphylococcus aureus & female & 3 & 6.92 & 0.52 & 0.0362 \\
\hline no Staphylococcus aureus & female & 12 & 8.65 & 1.23 & \\
\hline
\end{tabular}


Table 9. Comparison of mean index of condition $(\mathrm{kg})$ of northern fur seal pups with and without a species of pathogenic bacterium isolated from rectal swabs using a Student's ttest.

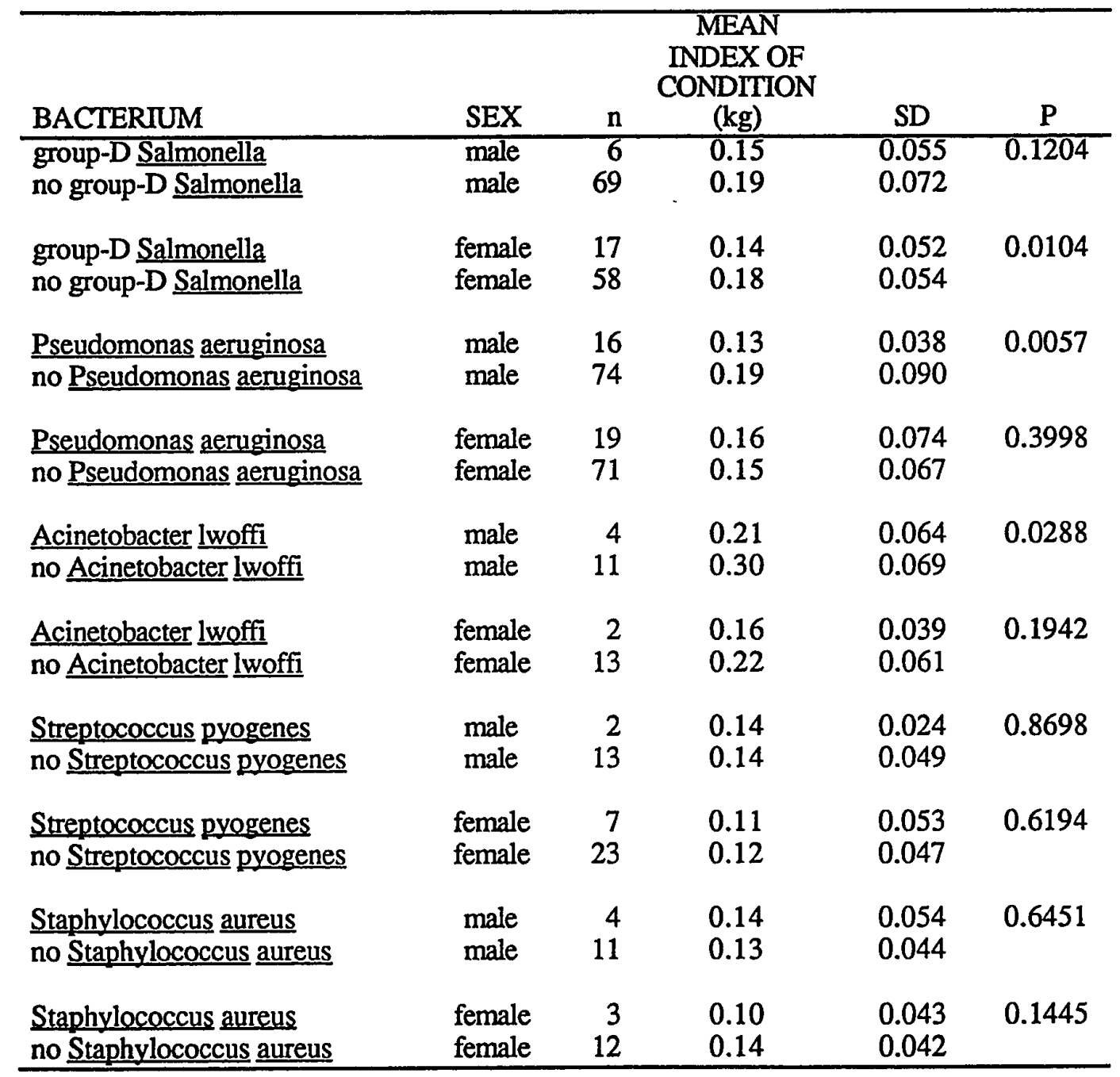


Table 10. Comparison of mean number of bacterial species $(\mathrm{F}=6.93, \mathrm{P}=0.0001)$ and mean number of species of pathogenic bacteria $(\mathrm{F}=3.36, \mathrm{P}=0.0001)$ per pup among rookeries of the Pribilof Islands and Medny Island using an ANOVA and Ryan-Einot-Gabriel-Welsch Q-multiple comparison test. Means with the same letter are not different significantly.

\begin{tabular}{lcl}
\hline ROOKERY & $\begin{array}{c}\text { MEAN NUMBER } \\
\text { OF BACTERIAL } \\
\text { SPECIES }\end{array}$ & $\begin{array}{l}\text { RYAN-EINOT- } \\
\text { GABRIEL-WELSCH } \\
\text { Q-GROUP }\end{array}$ \\
\hline LITTLE ZAPADNI & 4.667 & A \\
REEF & 4.300 & AB \\
VOSTOCHNI & 4.233 & ABC \\
ZAPADNI & 3.967 & ABCD \\
MORJOVI & 3.800 & ABCDE \\
EAST CLIFFS (GEORGE) & 3.533 & BCDEF \\
ZAPADNI (GEORGE) & 3.300 & BCDEF \\
NORTH (GEORGE) & 3.172 & CDEF \\
POLOVINA & 3.067 & DEF \\
TOLSTOI & 3.033 & DEF \\
LUKANIN & 2.967 & DEF \\
ZAPADNI REEF & 2.967 & DEF \\
URILIE (MEDNY) & 2.903 & DEF \\
POLOVINA CLIFFS & 2.867 & DEF \\
KITOVI & 2.800 & EF \\
GORBATCH & 2.433 & F \\
\hline & & \\
\hline & & RYAN-EINOT- \\
& MEAN NUMBER & GABRIEL-WELSCH \\
ROOKERY & OF SPECIES OF & Q-GROUP \\
\hline REEF & 1.333 & A \\
EAST CLIFFS (GEORGE) & 1.033 & AB \\
MORJOVI & 0.967 & ABC \\
VOSTOCHNI & 0.900 & ABC \\
ZAPADNI & 0.867 & ABC \\
LITLE ZAPADNI & 0.867 & ABC \\
ZAPADNI REEF & 0.867 & ABC \\
LUKANIN & 0.833 & ABC \\
POLOVINA CLIFFS & 0.700 & ABC \\
KITOVI & 0.700 & ABC \\
POLOVINA & 0.667 & BC \\
TOLSTOI & 0.600 & BC \\
GORBATCH & 0.600 & BC \\
URILIE (MEDNY) & 0.484 & BC \\
ZAPADNI (GEORGE) & 0.367 & BC \\
NORTH (GEORGE) & 0.345 & C \\
\hline & & \\
& PATHOGENIC BACTERIA & \\
\hline
\end{tabular}


Table 11. Comparison of mean number of bacterial species $(F=3.84$, $\mathrm{P}=0.0252)$ and mean number of species of pathogenic bacteria $(\mathrm{F}=4.82$, $P=0.0103$ ) per pup among St. Paul, St. George, and Medny Islands using ANOVA and Ryan-Einot-Gabriel-Welsch Q-multiple comparison test. Means with the same letter are not different significantly.

\begin{tabular}{lcc}
\hline & $\begin{array}{c}\text { MEANNUMBER } \\
\text { OF BACTERIAL } \\
\text { SPECIES }\end{array}$ & $\begin{array}{l}\text { RYAN-EINOT- } \\
\text { GABRIEL-WELSCH } \\
\text { Q-GROUP }\end{array}$ \\
\hline ST. PAUL & 3.867 & A \\
ST. GEORGE & 3.300 & AB \\
MEDNY & 2.967 & B \\
\hline \multicolumn{3}{c}{} \\
\hline & MEAN NUMBER & RYAN-EINOT- \\
ISLAND & OA SPECIES OF & GABRIEL-WELSCH \\
& PATHENICBACTERIA & Q- GROUP \\
ST. PAUL & & \\
ST. GEORGE & 1.100 & A \\
MEDNY & 0.700 & AB \\
\hline
\end{tabular}


Table 12. Linear regressions of pup mortality (\%) and number of live pups with mean number of bacterial species and mean number of species of pathogenic bacteria per pup, and frequency of occurrence of species of pathogenic bacteria for rookeries of the Pribilof Islands.

\begin{tabular}{|c|c|c|c|}
\hline & $\begin{array}{l}\text { REGRESSION } \\
\text { COEFFICIENT }\end{array}$ & $\begin{array}{c}\mathrm{F} \\
\text { VALUE }\end{array}$ & $\frac{\mathrm{P}}{\text { VALUE }}$ \\
\hline $\begin{array}{l}\text { PRIBILOF ISLANDS } \\
\text { ROOKERY MORTALITY WITH: }\end{array}$ & & & \\
\hline $\begin{array}{l}\text { MEAN NUMBER OF BACTERIAL SPECIES } \\
\text { MEAN NUMBER OF SPECIES OF PATHOGENIC } \\
\text { BACTERIA } \\
\text { FREQUENCY OF OCCURRENCE OF SPECIES } \\
\text { OF PATHOGENIC BACTERIA }\end{array}$ & $\begin{array}{l}0.112 \\
0.205 \\
0.307\end{array}$ & $\begin{array}{l}0.126 \\
0.437 \\
1.038\end{array}$ & $\begin{array}{l}0.7296 \\
0.5237 \\
0.3324\end{array}$ \\
\hline $\begin{array}{l}\text { ST. PAUL ISLAND } \\
\text { NUMBER OF LIVE PUPS WITH: }\end{array}$ & & & \\
\hline $\begin{array}{l}\text { MEAN NUMBER OF BACTERIAL SPECIES } \\
\text { MEAN NUMBER OF SPECIES OF PATHOGENIC } \\
\text { BACTERIA } \\
\text { FREQUENCY OF OCCURRENCE OF SPECIES }\end{array}$ & $\begin{array}{l}0.503 \\
0.211 \\
0.095\end{array}$ & $\begin{array}{l}3.393 \\
0.466 \\
0.510\end{array}$ & $\begin{array}{l}0.143 \\
0.209 \\
0.6573\end{array}$ \\
\hline
\end{tabular}


Table 13. Linear regressions of pup weight $(\mathrm{kg})$ and index of condition $(\mathrm{kg})$ with number of bacterial species and number of species of pathogenic bacteria per pup; mean weight and mean index of condition with mean number of bacterial species and mean number of species of pathogenic bacteria per pup, and frequency of occurrence of pathogenic bacteria for rookeries of the Pribilof Islands and Medny Island.

\begin{tabular}{|c|c|c|c|}
\hline & $\begin{array}{l}\text { REGRESSION } \\
\text { COEFFICIENT }\end{array}$ & $\begin{array}{c}\bar{F} \\
\text { VALUE }\end{array}$ & $\begin{array}{c}\mathrm{P} \\
\text { VALUE }\end{array}$ \\
\hline \multicolumn{4}{|l|}{ PRIBILOF AND MEDNY ISLANDS } \\
\hline \multicolumn{4}{|l|}{ WEIGHT OF PUPS WITH: } \\
\hline NUMBER OF BACTERIAL SPECIES & 0.036 & 0.612 & 0.435 \\
\hline NUMBER OF PATHOGENIC BACTERIA & 0.065 & 2.003 & 0.158 \\
\hline \multicolumn{4}{|l|}{ PRIBILOF AND MEDNY ISLANDS } \\
\hline \multicolumn{4}{|l|}{ MEAN WEIGHT OF PUPS WITH: } \\
\hline MEAN NUMBER OF BACTERIAL SPECIES & 0.233 & 0.746 & 0.430 \\
\hline MEAN NUMBER OF PATHOGENIC BACTERIA & 0.544 & 5.465 & 0.036 \\
\hline FREQUENCY OF OCCURRENCE OF & 0.481 & 3.915 & 0.069 \\
\hline SPECIES OF PATHOGENIC BACTERIA & & & \\
\hline \multicolumn{4}{|l|}{ PRIBILOF ISLANDS } \\
\hline \multicolumn{4}{|l|}{ CONDITION INDEX WITH: } \\
\hline NUMBER OF BACTERIAL SPECIES & 0.011 & 4.823 & 0.029 \\
\hline NUMBER OF PATHOGENIC BACTERIA & 0.009 & 3.958 & 0.047 \\
\hline \multicolumn{4}{|l|}{ MEAN CONDITION INDEX WITH: } \\
\hline MEAN NUMBER OF BACTERIAL SPECIES & 0.009 & 0.120 & 0.734 \\
\hline MEAN NUMBER OF PATHOGENIC BACTERIA & 0.041 & 0.554 & 0.470 \\
\hline $\begin{array}{l}\text { FREQUENCY OF OCCURRENCE OF } \\
\text { SPECIES OF PATHOGENIC BACTERIA }\end{array}$ & 0.073 & 1.030 & 0.329 \\
\hline
\end{tabular}



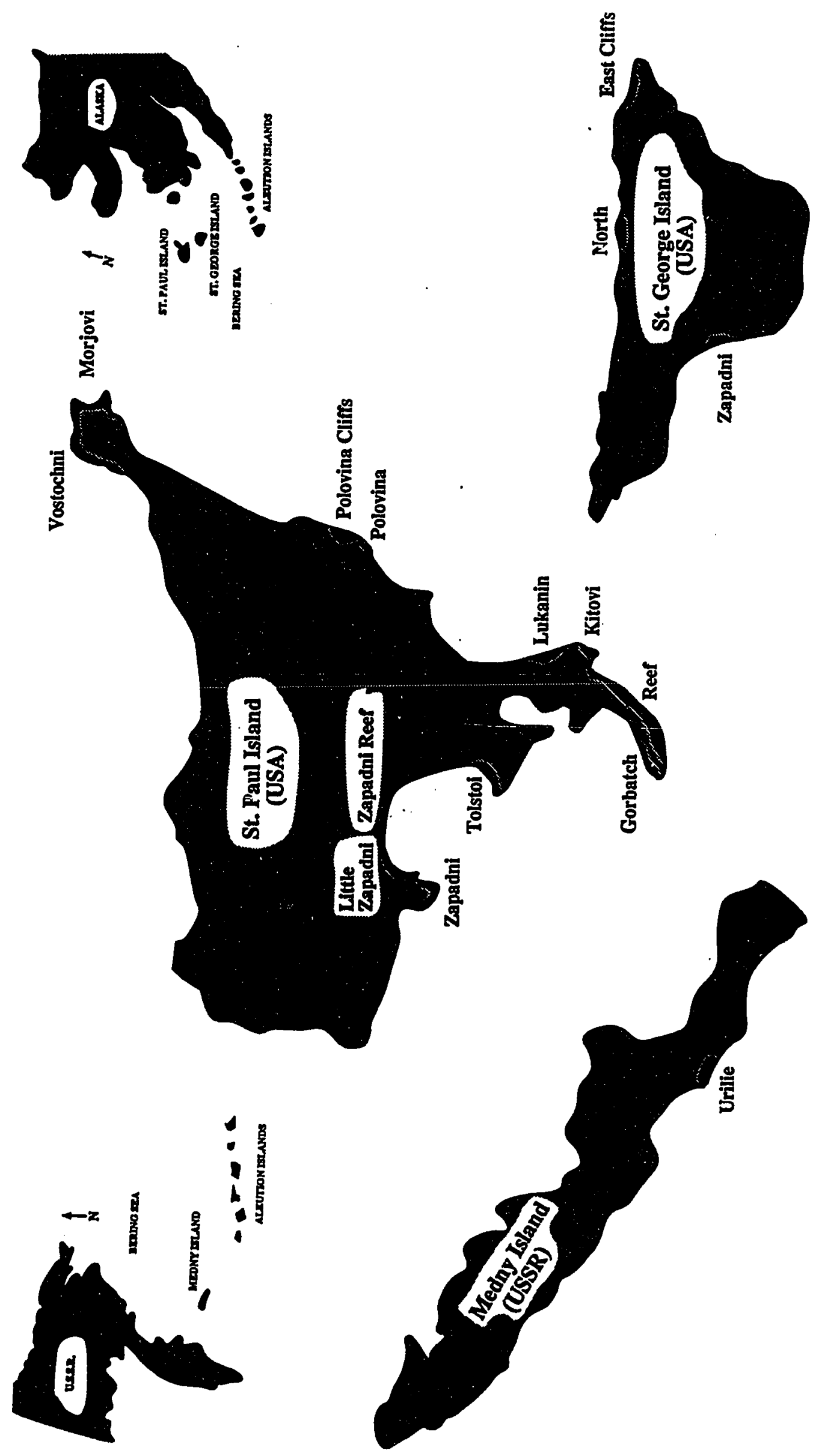

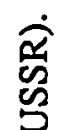
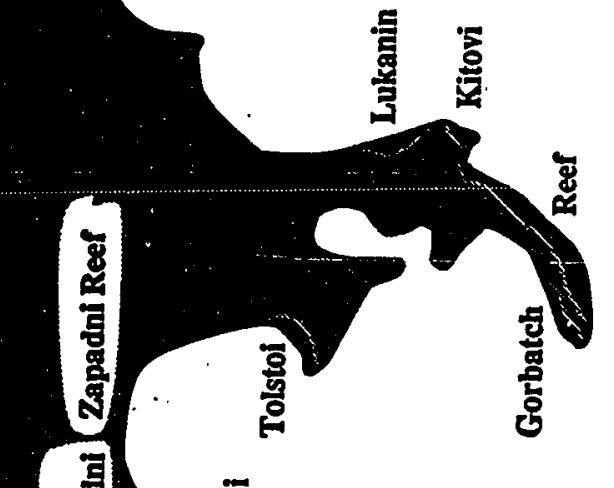

司

鄗易

b高

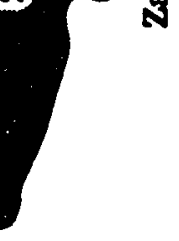




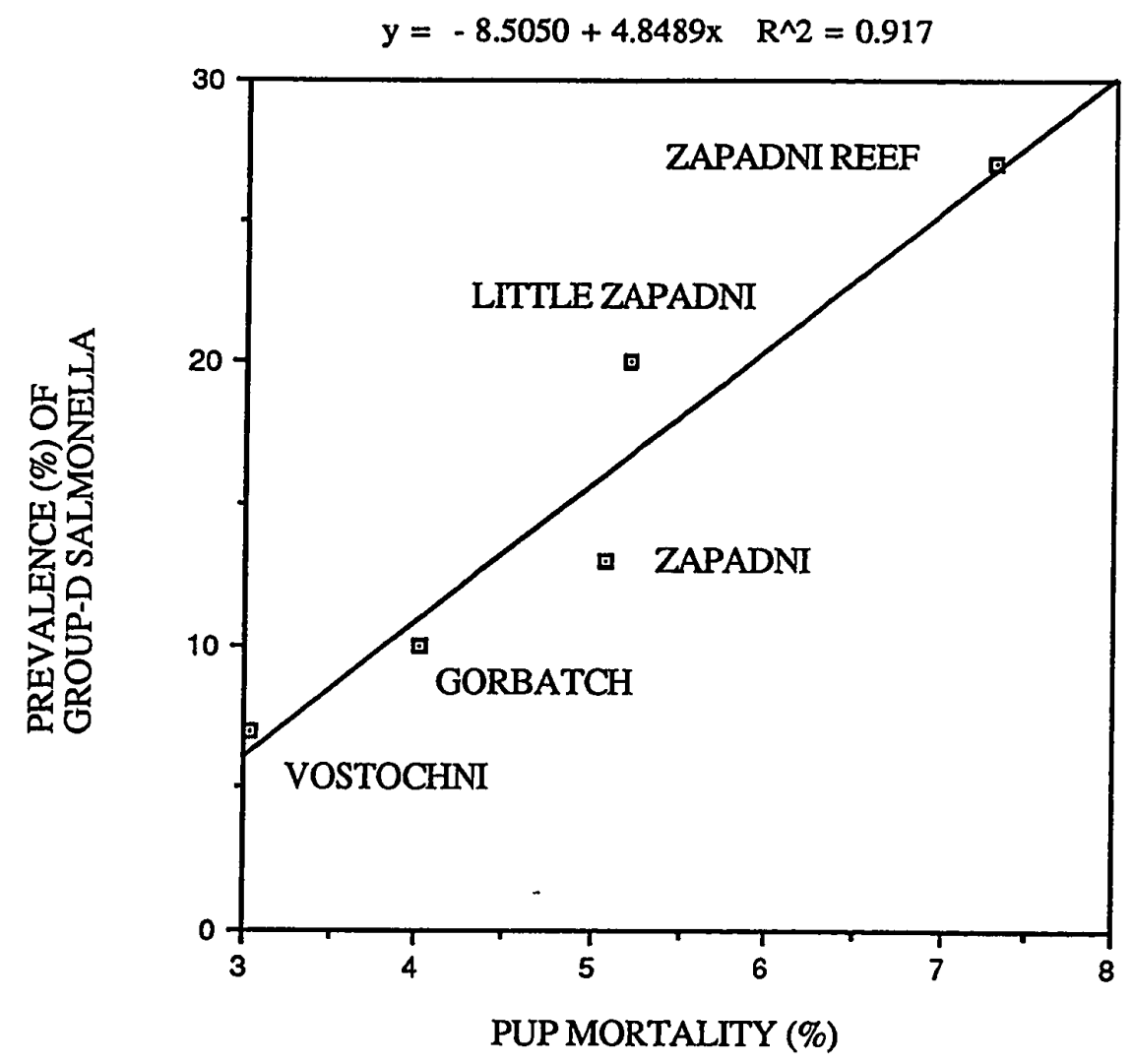

Figure 2. Linear regression of prevalence (\%) of group-D Salmonella and pup mortality (\%) for Little Zapadni, Zapadni, Zapadni Reef, Vostochni, and Gorbatch rookeries of St. Paul Island. 